Article

\title{
The Influence of Collaboration Initiatives on the Sustainability of the Cashew Supply Chain
}

\author{
Susana G. Azevedo ${ }^{1, *}$, Minelle E. Silva ${ }^{2}$ (D) , João C. O. Matias $^{3}$ (D) and Gustavo P. Dias ${ }^{2}$ \\ 1 CEFAGE-UBI, UNIDEMI, Department of Business and Economics, University of Beira Interior, \\ 6201-001 Covilhã, Portugal \\ 2 PPGA-Graduate Course on Business Administration, University of Fortaleza, Fortaleza 60811-905, \\ Ceará, Brazil; minelle.silva@unifor.br (M.E.S.); gustavopicanco@hotmail.com (G.P.D.) \\ 3 GOVCOPP-UA, Department of Economics, Management, Industrial Engineering and Tourism (DEGEIT), \\ University of Aveiro, 3810-193 Aveiro, Portugal; jmatias@ua.pt \\ * Correspondence: sazevedo@ubi.pt
}

Received: 28 April 2018; Accepted: 14 June 2018; Published: 19 June 2018

\begin{abstract}
Collaboration is emerging as a requirement for strengthening relationships among supply chain members and sustainability is rising as a real-world solution for different environmental issues. There are numerous studies that approach both perspectives, but there are still many questions about their relationship, mostly in the agri-food industry. Hence, this paper aims to address the influence of collaboration initiatives on the sustainability indicators of the cashew supply chain (SC). To reach this objective, a case study was performed among farmers belonging to the Cooperative of Cashews in the Piauí state (COCAJUPI), a local cooperative in Northern Brazil. Attending to the results, it is possible to state that the collaboration initiatives that have higher levels of implementation among research companies are the "trust among supply chain members" and the "sharing of standards information". Moreover, the size of companies in the cashew SC does not influence the level of implementation of collaboration initiatives. The findings of this study demonstrate that the farms' area of the companies from the cashew SC does not have a significant influence on their sustainability indicators. Furthermore, a weak relationship exists between the collaboration initiatives and the indicators associated to the three dimensions of sustainability.
\end{abstract}

Keywords: collaboration; supply chain sustainability; agri-food industry; cashew farmers; case study

\section{Introduction}

Recent studies have demonstrated several interactions between collaboration and sustainability, such as cleaner production [1], sustainable consumption [2], the adoption of environmental technology [3], and sustainability governance [4]. Despite this broad area of focus, there has been an emergence of studies pertaining to the food supply chain perspective that analyze this relationship [5-7]. The increased attention given by the academic community to the food supply chain (SC) is justified by the complex sustainability requirements of the agri-food industry, which have compelled heterogeneous stakeholders to collaborate towards better sustainability outcomes [7].

Collaboration among multiple businesses for environmental improvements should be a key issue for Sustainable Supply Chain Management (SSCM) [8]. Soylu et al. [9] point out that SC collaboration is a common way for companies throughout the SC to share information, make strategic alliances, and reduce overall costs, also in terms of sustainability. Collaboration is also seen as necessary to develop, apply, and establish new innovative ideas and practices, and is linked to the socio-economic and ecological sustainability of the agri-food system [10]. It contributes also to reduce transaction costs, 
facilitate costs avoidance, develop a shared vision, initiate a learning process, and allows small actors to increase their impact on the agri-food system [11].

Regarding food production, the Food and Agriculture Organization (FAO) [12] states that global food production must increase by $60 \%$ by 2050 to meet the demands of the growing world population and to reduce world hunger, while there is also a need to observe resource capacity and to reduce food waste at the same time. Therefore, the sustainability challenges in the food industry are numerous, requiring innovative approaches and strategies. The work of Chen et al. [13] states that companies perform SC collaboration for sustainability, with an integrated perspective, which includes collaboration with suppliers, customers, competitors, and other organizations. This will contribute to enrich the companies' resources and enhance their capability for achieving an improved sustainable performance.

Supply chain collaboration (SCC) takes a relational perspective among different actors, which suits our analysis of supply chain sustainability (SCS). SCC is a partnership between at least two independent SC members that targets common goals and mutual benefits [14]. Thus, collaboration emerges as an element that contributes to improving SC performance. This performance can only be assessed using correct sustainability indicators. This paper aims to study the influence of collaboration initiatives on sustainability indicators of the cashew SC.

This paper's main argument is that supply chain members, for continued sustainability, should be engaged in the 'collaborative paradigm' [15]. A case study of the cashew SC in northern Brazil, in which farmers are organized in cooperatives to better perform their activities, is explored. A cooperative is a type of farmers' organization that gives more power and bargaining capacity to their members, representing a typical agri-food supply chain member [6]. Despite this, there are other factors that can influence the level of implementation of certain collaboration initiatives, such as trust and sharing activities (i.e., information sharing, risk and reward sharing, and resource sharing) $[7,16]$. By completing an analysis of the relationships among several SC members' partnerships, it will be possible to understand the sustainability practices of each local cashew farmer.

According to Dania et al. [7], collaboration is vital in empowering farmers and is most important in low socio-economic status communities. This is the case in northern Brazil, a region that has faced large periods of drought during the last six years. Currently, farmers are facing several barriers that are preventing their empowerment, such as low negotiation power, poor education, irregular production outcomes, low cooperative behavior awareness, and a high dependence on rain seasons. These aspects highlight their vulnerability and reduce the empowerment capacity of local farmers when they act in isolation and without considering their participation in cooperatives and SCs. According to Candelo et al. [17], the empowerment of stakeholders is crucial to change the vulnerability factor within the supply chain. In addition, in local communities, community participation is crucial to economic development and the construction of social structures [18]. Considering these points, which have been highlighted by researchers as being important for the relationships between collaboration and sustainability, the research question of this work is: What are the relationships between collaboration initiates and the sustainability indicators of the cashew supply chain?

In this work, collaboration initiatives in the agri-food industry and sustainability indicators are suggested to study the influence of these initiatives on the sustainability practices of companies in the cashew SC. Therefore, based on the analysis of horizontal collaboration, we only analyze the upstream supply chain. Léon-Bravo et al. [5] claim that different stages contribute to improve the SC performance, however, by considering the low empowerment of cooperative farmers, the initial stages are our research focus. To attend the research question, we analyze the COCAJUPI-cooperative of farmers-as the lead organization of the cashew nut SC, with specific attention to its influence in the Piauí state and contribution to the local development. Piauí has a very low position (25th out of 27th) among the Brazilian states regarding the Human Development Index (HDI) [19]. However, it is the third biggest producer of cashew nuts in the country [20]. 
Initially, this paper will present a theoretical background and hypothesis of the research. The next section will describe the methodological process. Section 4 will present the results, which supports the discussions developed in Section 5. Finally, in Section 6, conclusions are drawn.

\section{Theoretical Background}

\subsection{Sustainability in the Agri-Food Industry}

Agri-food companies progressively consider sustainability as an important part of their value proposition for several reasons. Investors often face strong pressures to invest in socially responsible companies [21]. Additionally, governments are often compelled to set minimum sustainability standards, such as targets for emission reductions. Research claims that the buying behavior of consumers is also changing in favor of sustainable products [22,23], though this may not often be the case in areas suffering from difficult economic conditions or poverty.

The agri-food industry generates greenhouse gas (GHG) emissions at all stages of its supply chain, from the manufacturing and distribution of inputs used at the farm level to food processing, preparation, and distribution. Agriculture is directly responsible for about 10-12\% of global GHG emissions [24,25]. These figures have been confirmed by the Environmental Impact of Products (EIPRO) [26] and studies have proven that food products are responsible for 20-30\% of the environmental impacts of total consumption. Recognizing the need for more sustainable production, leading corporations in food processing have begun to implement SC strategies, targeting improved environmental, social, and economic performance [27].

The concept of sustainability in the food sector is quite complex and is derived from a set of social and environmental performance issues [28]. The discussion of corporate social responsibility (CSR) in the food chain highlights the extensive environmental impacts related to the preservation of natural resources and ecosystems, as well as the broad range of social issues tied to working conditions and the nature of the products for consumption [29]. This complex range of social and environmental issues results in inevitable trade-offs, which represent a challenge for food processors to market their products as 'delivered to final clients through a more sustainable supply chain' [30] (p. 852).

Lastly, food processors must also consider the practical issues linked to context. Common challenges faced in emerging markets include weak legal enforcement and a lack of knowledge, adequate training, technology, infrastructure, and capital required to invest in sustainable supply chain management (SSCM) [31-33]. In addition, local stakeholder expectations can influence the type of SSCM practices a firm chooses to engage in. Therefore, it is necessary to understand the institutional environment, including the official regulatory environment, common business practices, and the unformal rules governing everyday life [33].

To support the development of sustainable agri-food SCs, it is essential to increase knowledge about the economic, environmental, and social performances of the various stages in these supply chains [34]. Agri-food SCs account for a significant share of production and consumption, and have significant effects on economic growth, social welfare, development, and the natural system [35]. The environmental and socio-economic costs associated with the externalities of the intensification of food production are also increasing dramatically [36]. Pollution in the soil and water has been augmented, biodiversity in agricultural systems and its surrounding ecosystems has been reduced, natural resources have been overexploited [37], negative impacts on human health have increased, and ethical issues have arisen [35]. For this reason, concerns have been raised as to whether production is consistent with sustainability [38].

Wilson [39] declares that the best way to preserve biodiversity is by giving it a real economic value, a theory particularly relevant to agrobiodiversity. Consequently, in recent decades, the conscious consumer has started to develop a new approach to food consumption by considering quality, tradition, and local sources. For instance, the European Union has developed systems that valorize high quality 
food through specific labels that are currently widely used in all member countries and testify to the strong relationships between crops, food, local traditions, and cultures.

Over the past 50 years, agriculture has undergone considerable changes that have been strongly influenced by the specialization and standardization of production, as well as technology and wage relations [40]. These factors have become essential components of the agricultural industry. Consequently, monocultures have prevailed and the natural environment has been drastically altered. At the same time, many adverse effects of agricultural modernization are apparent, including increased and widespread pollution, the rapid decay of agrobiodiversity, and the loss of traditional farming practices, cultures, and historical local knowledge. Generally, a sustainable agri-food system (SAFS) must produce quality products and be economically viable, ecologically feasible, socially fair, and culturally acceptable. Evaluating such a system requires the goals of the SAFS to be clear, the stakeholders to be identified, and the objective criteria for measuring goals to be established, scored, and weighted [41].

Sustainability Indicators for the Agri-Food Industry

Indicators can be defined as quantitative measures against which some aspects of the expected performance of a policy or a management strategy can be assessed [42]. They are used to make complex systems understandable and to offer meaningful information [43-46]. Furthermore, they have been important tools in assessing agricultural sustainability $[47,48]$. According to some authors, performance indicators should respect a set of conditions: (i) Should be measurable [47,49]; (ii) should be sensitive to variations [43,50]; (iii) should be relevant to the case study [43,49]; and (iv) should be related directly to the theme established by a group of experts.

In the literature, indicators for sustainability assessment should follow several requirements, such as: (i) For each dimension of sustainability (economic, social, environmental), at least one indicator should be selected that indicates the multi-dimensional character [51,52]; (ii) the economic dimension should contain an indicator for profitability [51,53]; (iii) one indicator should reflect societal support, indicating policy relevance [53-55]; (iv) preferably, broad indicators should be selected to provide a wide range of information [54]; and (v) data should be available to quantify the indicators [47,50-52,55].

Currently, there are two ways of defining sustainability performance. The first is product-based and the second is corporate-based. Product-based sustainability performance indicators include product ecological footprints, such as carbon [56] and water footprints [57]. Though not recognized as such, price is also a product-based sustainability indicator, albeit, a financial one. The focus on products is probably because products are considered to embody all of the events that occur from the beginning of production [58]. Therefore, product-based indicators represent the impacts of the entire SC. Corporate sustainability performance indicators, on the other hand, are measured using the organization as an entity. Sustainability standards and guidelines, such as the Global Reporting Initiative (GRI) [59], focus mainly on the impacts of corporate sustainability.

In the agri-food industry there are also sets of tools and reporting systems, which include:

(i) BASF's AgBalance [60] - it is a holistic method developed by the chemistry company BASF for assessing sustainability in agriculture using 69 weighting indicators of environmental, social, and economic performance, and is based on over 200 evaluation criteria to produce aggregate sustainability indicator results;

(ii) the Livestock Environmental Assessment and Performance (LEAP) Partnership Guidelines-a multi-stakeholder initiative convened by the United Nations FAO [61] in which the aim is to advance harmonized methods for life cycle-based environmental assessments in the livestock sector;

(iii) PAS 2050-a methodological, life cycle-based, greenhouse gas-accounting standard developed by the British Standards Institute (BSI) [62] in cooperation with the Defra and the Carbon Trust, with input from industry and other stakeholders. It intends to provide greater consistency in the evaluation of supply chain GHG emissions for products and services; 
(iv) the Stewardship Index for Specialty Crops (SISC) [63] — a multi-stakeholder initiative to develop sustainability assessment metrics for specialty crop supply chains. These metrics are intended to support operators in benchmarking, comparing, and communicating their performance;

(v) the "Fieldprint" Field to Market Calculator-a freely available tool for evaluating the environmental performance of corn, cotton, rice, wheat, potato, and soybean production in the United States. The employed indicators are land use, conservation, soil carbon, irrigation water use, water quality, energy use, and greenhouse gas emissions. The calculator uses farm-specific data along with supporting datasets and methodologies from various sources.

(vi) the "Sustainability Performance Assessment Version 2.0-Towards Consistent Measurement of Sustainability at Farm Level" (published by the SAI Platform in 2014) [64]-a report meant to guide developers in farm-reporting tools, indicators, methodologies, and approaches. It includes recommendations for methods and indicators specific to climate and energy; pesticides; soil quality; water quantity; nutrients; biodiversity; land use; and animal welfare.

Despite all these elements, it is still necessary to condense a set of indicators that directly support the study of sustainability in the agri-food industry. Therefore, in the literature review, the indicators in Table 1 are suggested to assess the sustainability of agri-food SCs.

Table 1. Sustainability indicators.

\begin{tabular}{|c|c|}
\hline Social Indicators & Authors \\
\hline $\begin{array}{l}\text { Number of meetings attended by the group of producers per year to develop } \\
\text { their knowledge of different aspects of production }\end{array}$ & Peano et al. [65] \\
\hline $\begin{array}{l}\text { Number of regular relationships that the group of producers have with local } \\
\text { institutions (regions/provinces/municipalities) }\end{array}$ & Peano et al. [65] \\
\hline $\begin{array}{l}\text { Social inclusion (all stakeholders are included, e.g., young, women, religious, } \\
\text { or nonreligious producers) }\end{array}$ & Peano et al. [65] \\
\hline Sharing of decisions and choices & Peano et al. [65] \\
\hline Fair standards of living for agricultural and rural communities & European Commission [26] \\
\hline \multicolumn{2}{|l|}{ Environmental Indicators } \\
\hline Land use (ha/kg) & $\begin{array}{c}\text { FAO [66]; } \\
\text { van Asselt et al. [67]; } \\
\text { Haverkort and Hillier [68] }\end{array}$ \\
\hline Water use (ha/kg) & van Asselt et al. [67] \\
\hline $\begin{array}{l}\text { Energy use (Mj fossil fuels } / \mathrm{kg} \text { ): The sum of the energy used during primary } \\
\text { production (expressed in } \mathrm{CO}_{2} \text { equivalents) and during transport }\end{array}$ & $\begin{array}{l}\text { van Asselt et al. [67]; } \\
\text { Carbon Trust [69]; } \\
\text { De Boer et al. [70]; } \\
\text { Scheer et al. [71]; } \\
\text { Peano et al. [65] }\end{array}$ \\
\hline $\begin{array}{l}\text { Amount of water from alternative sources that is used at farms; for example, } \\
\text { recycling and rainwater utilization }\end{array}$ & Peano et al. [65] \\
\hline Type of material used to pack the product (recyclable and/or biodegradable) & Peano et al. [65] \\
\hline Pesticide use (g active compounds/kg juice and cashews) & Peano et al. [65] \\
\hline \multicolumn{2}{|l|}{ Economic Indicators } \\
\hline Relative employment (\% of the total employment) & van Asselt et al. [67] \\
\hline Self-sufficiency (imports/total production of agricultural products) & van Asselt et al. [67] \\
\hline $\begin{array}{l}\text { Optimum utilization of the factors of production; in particular, labor and the } \\
\text { increase of agricultural productivity }\end{array}$ & van Asselt et al. [67] \\
\hline
\end{tabular}

The indicators should be used to define the sustainability of several agri-food industries and to support the understanding of how other elements can influence a sustainability index. Thus, it is relevant to consider them as starting points in debating agri-food sustainability, then to develop 
relations with other elements that surround the companies' governance. A central theme of this paper is to analyze the influence of collaboration initiatives on the sustainability indicators of the cashew SC.

\subsection{Supply Chain Collaboration for Sustainability}

Collaboration is a meta-concept that has received several interpretations by both organizations and individuals [72]. However, and according to the same author, since collaboration is a very broad term, it is still necessary to clarify how it should be applied to SCs. Collaboration refers to organizations and enterprises working together to achieve specific goals $[6,14]$, which clearly indicates the contributions of collaboration in an SC context. There are many ways to study collaboration in SCs. Barrat [72] considers two types of collaboration: Vertical collaboration (for example, the supply-side and demand-side (Blome et al. [73])) and horizontal collaboration, which is related to external collaboration. In this context, the concept of supply chain collaboration (SCC) is defined as "two or more chain members working together to create a competitive advantage through sharing of information, making joint decisions, and sharing benefits, which result from greater profitability in satisfying end customer needs than acting alone" [74,75].

Collaboration type depends on how companies integrate their supply chains. For instance, Touboulic and Walker [76] consider that companies often engage different types of suppliers, which involves, for example, the inclusion of small and medium companies in the strategic suppliers' board. The application of collaboration to the agri-food industry has been researched through studies that demonstrate its relevance, which is clear when related to sustainability [5-7]. According to Blome et al. [73], sustainability collaboration can be observed as a pathway to address sustainability issues. Hence, it is evident in the literature that sustainability is related to collaboration.

Going beyond commercial relationships, collaboration among several actors in an SC is a strong pathway for facilitating sustainability outcomes $[6,77]$. To achieve sustainability via collaboration, it is relevant to observe that more than simply a strategic action has a high level of performance in the market [15], because collaboration is a cultural element that contributes directly to organizational behavior. Beske and Seuring [78] state that collaboration is both a structure and a process to achieve SSCM, which supports the organizational culture perspective, since it should be part of daily operational activities (such as interdepartmental meetings) and continually used in the market.

The organizational culture approach towards SSCM was first presented by Carter and Rogers [79]. According to them, from a strategic perspective, sustainability needs to be part of a company's core. Following the idea of a collaborative culture, Barrat [72] defends that trust, mutuality, information exchange, and openness and communication are the main elements representing that perspective. These elements can support the progression from collaboration to inter organizational relationships. Also, Beske, Land, and Seuring [80] and Beske and Seuring [78] claim that other activities should be considered as a part of collaboration for SSCM. Therefore, for a better understanding about the contribution of collaboration to sustainability in SCs and attending to the same authors, it is possible to use elements, such as technological integration, logistical integration, enhanced communication, and joint development, as indicators that integrate the construct. These elements represent the required structure and/or activities that directly support collaboration.

Touboulic and Walker [76] claim that true collaboration is required, but is difficult to attain. Therefore, some elements are required to facilitate the operational approach of collaboration to solve real-world problems. With a focus on agri-food industry literature, Dania et al. [7] found that there are ten key factors that influence collaboration towards sustainability: (1) Joint efforts (i.e., collaborative activities to support decision making); (2) stability (i.e., awareness of common goals in the SC); (3) collaboration value (i.e., co-creation behavior among SC members); (4) adaptation (i.e., ability to adjust /needs); (5) commitment (i.e., dedication to maintain or improve relationships); (6) power (i.e., ability to influence others in a relationship); (7) continuous improvement (i.e., ability to improve performance); (8) coordination (i.e., ability to manage relationships); (9) trust (i.e., level of confidence 
between different parts); and (10) sharing activities (i.e., cover assets, benefits, and risks regarding the informational process).

Using the argument of van Hoof and Thiell [81], the collaboration capacity depends on "exchanging information, drawing and sharing group values, solving problems, and new reasoning". In this capacity, trust is the most prominent and critical aspect for not only the effectiveness of a collaboration, but also improving sustainability performance $[13,76]$. The trusting relationship can promote cooperation in the supply chain and, once trust develops, the shared vision between actors and facilitate social ties [82]. Following that point of view, trust is fundamental to understand individuals' behaviors in the social network and how social actors are related to each other to implement collaboration initiatives by improving supply chain sustainability.

According to the literature, it is clear that several elements influence the relationship between collaboration and sustainability. However, agri-food literature suggests that patterns regarding trust and the sharing of activities (i.e., information sharing, risk and reward sharing, and resource sharing) are the most important to SCC sustainability [7]. Both initiatives are enabling SCC [16,83] and can support other elements inside the collaboration approach, mostly because of their impact on firm performance. Thus, if these two collaboration initiatives are developed in SCs, there is a chance of assuming collaboration as a practice among their members. As argued before, trust is necessary to develop strong relationships and sharing activities (i.e., information-centered collaboration), meaning availability of flows into SCs, resulting in improvements of the SCs performance [16]. Despite being important, both elements are not enough to reach collaboration; however, they are influential in determining how to observe collaboration among SC members, mostly related to sustainability. Attending to this literature review, the following hypotheses are suggested in this study:

Hypothesis $\mathbf{1}$ (H1). Trust is a collaboration initiative that has a high level of implementation among companies in the cashew industry.

Hypothesis 2 (H2). Sharing activities are a collaboration initiative that has a high level of implementation among companies in the cashew industry.

According to Barratt [72], more important than observing collaboration is understanding its context, which includes debates about when to collaborate and with whom. Thus, following the arguments of León-Bravo et al. [5], larger companies often feel higher external market pressures to demonstrate sustainability as they are closer to the final consumer. In food SCs, large processors adopt practices to support community and consumer education through external collaboration. This type of collaboration involves establishing joint planning and decision-making for specific events or issues, with explicit and, sometimes, tacit knowledge-sharing for event collaboration [84,85]. With regards to the literature review, the following hypothesis is suggested:

Hypothesis 3 (H3). There are differences in the level of implementation of collaboration initiatives among companies with different sizes.

These elements demonstrate how sustainability is influenced by the SCC and they also provide new insights into developing research on the topic. Beyond the analysis of collaboration initiatives related to sustainability, it is necessary to understand the main characteristics of the research SCs. Therefore, for a better understanding about the proposal of this research, a recognition of the characteristics of the cashew SC is necessary, especially in relation to sustainability.

\subsection{Sustainability in the Cashew Supply Chain}

There is little research focusing on the sustainability of the cashew SC. Although some studies have been developed around the world, such as greenhouse emission reduction in West Africa [86], rural development in Mozambique [87], the empowerment of women in the Philippines [88], 
and socio-economic factors in India [89], most of the works focused on sustainability have been developed in Brazil [90,91]. For instance, Figueirêdo Júnior [90] discusses several major factors, such as the supply and demand behavior, the value chain of the sector, the business environment, and possible external events that influence the competitiveness of the cashew nut industry in Brazil. This research highlights the importance of the cashew agribusiness, specifically in northern Brazil, to the socioeconomic performance of the country, the number of employed people, and the products destined for export.

The highest concentration (99.4\%) of areas of cashew production in northern Brazil are mainly in the states of Piauí, Rio Grande do Norte, and Ceará [20]. Sustainability concerns are observed primarily in the state of Ceará, which represents a major Brazilian cashew producer $(62.9 \%$ out of the $99.4 \%$ figure), despite the drought faced by this region [20]. In this state, innovative actions on behalf of the local system's organization are performed to further develop the cashew agribusiness productive chain [91]. These elements are used as a reference to understand the sustainability elements surrounding the Piauí state production.

Focusing on the environmental dimension of sustainability, Laroche et al. [92] claim that the quantification of the environmental performance of agri-food production, such as cashew juice, allows for increased competitiveness of companies in the food market, turning the attention of consumers towards environmentally friendly products. Regarding the cashew SC, most studies focus on marketing and entrepreneurship [93], environmental impact [94], contribution to food security [95], and the structure of social relationships within chain members [96]. Concerning the economic dimension of sustainability, the cashew nut is the primary product exported from Ceará, having generated US $\$ 91,730,430$ in 2017 , about three quarters of the $\$ 114,089,701$ total value of cashews exported by Brazil [97].

The social dimension of sustainability is still rarely observed in research pertaining to the cashew SC in northern Brazil. Oliveira and Ipiranga [91] argue that cleaner production in the sector allows for the introduction of social technologies that increase the inclusion of social concerns. Focusing on Brazilian nuts in Amazonia, Brose [98] found that working conditions should be the focus of agri-food because sometimes production develops modern slavery practices, depending on how the social dimension is performed. According to D'Souza and Ikerd [99], all farms have some impact on the environment and the local community where they are sited. The type of impact and the intensity are likely to be different depending on the area considered. Small farms possess characteristics that, individually or as a group, make them more likely to contribute to sustainability objectives. Therefore, there is a lack of understanding about this dimension and a gap emerges about whether the farm areas of the cashew SC influence their sustainable behavior. Thus, the following research hypothesis is proposed:

Hypothesis 4 (H4). The farm areas of companies that belong to the cashew supply chain influence the indicators of sustainability of the companies that belong to the cashew SC.

The cashew SC has a very specific flow of processes in its production. Figure 1 summarizes this process. This type of plantation depends on the region's winters, since no technology is used to prepare the soil to produce cashews. However, it is important to highlight that, in past years, drought periods have impacted performance [20]. The harvest is done by hand, which indicates that production is very craft-focused. The main by-products of cashews are the cashew nut and a type of juice, called cajuína, that is sold in local, as well as international, markets. However, throughout the years, farmers and agro-industries have been developing new by-products, since there is a high amount of waste in the SC. It is necessary to understand sustainability as a whole to create new strategies to change SC performance in the market. 


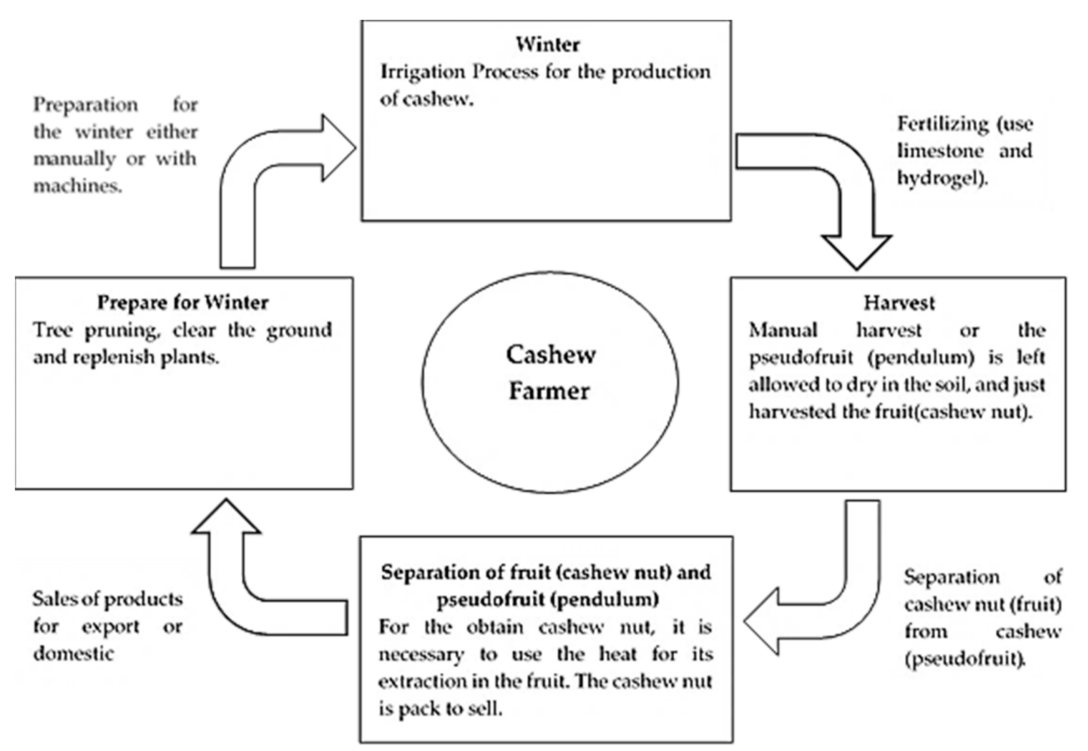

Figure 1. Flowchart of the cashew production process.

According to Oliveira and Ipiranga [91], clean production and observing its impact on sector performance is a requirement of reaching social and environmental management. However, as already mentioned in this section, the cashew SC is trying to adopt more sustainable practices through the introduction of the Triple Bottom Line (TBL) actions, which are not based more on the environmental dimension per se. One requirement for improving sustainability is to consider local elements and how they can effectively change SC performance. Related to this perspective, there is a need to understand the influence of collaboration initiatives on the sustainable behavior of companies from the cashew SC, which is the focus of this research.

\subsection{Collaborative Initiatives and Sustainability in Supply Chains}

Applying the collaboration initiative approach to understand SC sustainability assumes a relevant research topic, since, as presented so far, there is no clear relation. Dania et al. [7] claim that "an effective and high-quality collaboration for sustainable agri-food supply chains can facilitate the farmers to access resources, opportunities, and benefits equal to those of other supply chain stakeholders". Also, collaboration between multiple actors is necessary to develop, apply, and establish new innovative ideas and practices, and is linked to the socio-economic and ecological sustainability of the agri-food system [10]. This is directly related to sustainability performance because the way in which collaboration is practiced may influence the achievement of sustainable results. Thus, it is critical to develop research focusing on this relationship.

According to Gimenez and Tachizawa [100], collaboration with suppliers is a governance mechanism and has a direct influence on sustainability performance. However, Blome et al. [73] suggest that collaboration does not directly impact sustainability or market performance. They claim this because they found that sustainability is only possible in collaboration if there are external partnerships; and SC members must lead sustainability internally in their practices before spreading it to the SC. Sustainable collaboration assumes a new profile in the market, which depends on these definitions. For this research, the following hypothesis has been proposed:

Hypothesis 5 (H5). The level of implementation of collaboration initiatives influences some sustainability indicators of the companies from the cashew SC.

There are debates in the literature relating to both sustainability performance and collaboration $[5,101]$, but they are still inconclusive. Hence, advancements should be made in the understanding of this 
relationship, since it has a direct influence on how SC sustainability should be observed. As presented by Blome et al. [73], sustainable collaboration requires specific resources for joint activities to address sustainability issues. However, the way in which the level of collaboration contributes to SCS is a very interesting topic in the field of sustainable operations management.

\section{Research Methods}

The main objective of this research is to analyze the influence of collaboration initiatives on the sustainability indicators of the cashew SC. To attain this objective, a case study was performed among farmers associated to the Cooperative of Cashews in the Piauí state (COCAJUPI), which represents a local cooperative in Northern Brazil.

Perry [102] and Rowley [103] state that a case-study approach is appropriate when the boundaries of a phenomenon are not only unclear, but also when there is no control over behavioral events. In this research, the boundaries (the influence of collaboration initiatives on sustainability indicators of the cashew SC) are still relatively vague. To this end, 43 farms of cashews and other agricultural productions, livestock, and beekeeping were analyzed to identify the type of collaboration initiatives and sustainability behaviors that have been adopted by research companies and the relationship between them.

Yin [104] states that case studies can be exploratory, descriptive, or explanatory. Because there is little empirical evidence this research is descriptive and explanatory in nature. Descriptive because it identifies the level of implementation of collaboration initiatives and the type of sustainability indicators. Explanatory because it focuses also on the influence of collaboration initiatives on social, economic, and environmental indicators of sustainability.

From the perspective of Rosenzweig and Singh [105], as the SC environmental behavior may differ from country to country, it is desirable to focus on one SC in one country before moving on to cross-supply chains and cross-country studies. Attending to this argument in our study, a single SC research design concerned with the cashew supply chain in Northern Brazil was chosen.

\subsection{Sample Selection of Companies from the Cashew SC}

To develop an in-depth knowledge and sound experience of the collaboration initiatives and sustainability of the cashew SC, a purposeful sampling was adopted [106]. That is, a non-probability sampling technique was used [107], since all the research companies belong to the same cooperative in northern Brazil. Okoli and Pawlowski [108] provide a detailed discussion of the process in which respondents should be selected for a rigorous approach. Considering this process, it is crucial to identify the kind of knowledge required for an expert entering the study. In this research, two different sets of experts were selected: Academic researchers (for the pre-test) and professionals (for the survey).

To identify eligible academics for the pre-test of the questionnaire, the following two criteria were followed: The candidates must have; (i) a sound knowledge and understanding of collaborative initiatives and (ii) involvement in agri-food industry research topics. To obtain the most valuable opinions, only academics who met these criteria were considered. Ultimately, three academics from the FCT/University of Nova de Lisboa, the University of Beira Interior, and the ESCE Escola Superior de Ciências Empresariais were involved in the pre-test. The criterion used to select the professionals was that they must work as cashew farmers in the Piauí state in northern Brazil. Piauí is the second largest exporter of cashew nuts in Brazil [97].

To develop the research, the farmers were selected from those associated with the Cooperative of Cashews in the Piauí state (COCAJUPI), a local cooperative. We used this research criterion as it facilitated contact with small producers based in very small cities, such as Mosenhor Hipólito, Ipiranga, Francisco Santos, Jaicós, Vila Nova, Pio IX, and Campo Grande. COCAJUPI started their activities in 2005 and is focused on organizing and spreading the production of cashew and its by-products through eight small cooperatives. Since 2015, the fair-trade label was accepted in three out of the eight small cooperatives, which demonstrates a new incentive for sustainability. The main goal of the 
cooperative is to have all cooperatives with this label. In a similar way, organic production is the next step of the company to produce cashew nuts in the region.

The sample that comprises part of this research was formed by cashew production companies that are dedicated to producing cashews and other agricultural productions, livestock, and beekeeping. The cashew is the main product these companies use to produce the following by-products: Cashew nut and cashew fruit, and cashew nut and cajuína (a type of juice). Also, most of the companies that make part of the cashew SC (38 companies) have a planting area between one and 10 ha; only four companies have between 11 and 15 ha and three have 16 ha or more. A primary customer in the SC is the Cocajupi (comprised of 40 farms); only two farms sell their products directly to local markets and three farms to intermediators. Moreover, 43 farms have the Cocajupi as their main partner in the SC (Table 2).

Table 2. Sample profile (Number of companies).

\begin{tabular}{|c|c|}
\hline Core Business & $\begin{array}{l}\text { Cashew production ( } 45 \text { companies) } \\
\text { Beekeeping ( } 6 \text { companies) } \\
\text { Livestock ( } 29 \text { companies) } \\
\text { Other agricultural productions (42) }\end{array}$ \\
\hline Main product produced & $\begin{array}{l}\text { Cashews ( } 37 \text { companies) } \\
\text { Cashews and honey ( } 2 \text { companies) } \\
\text { Cashews and livestock ( } 3 \text { companies) } \\
\text { Other agricultural productions ( } 3 \text { companies) }\end{array}$ \\
\hline By-products & $\begin{array}{l}\text { Chestnuts and Cajuína ( } 12 \text { companies) } \\
\text { Chestnuts and cashew fruit ( } 25 \text { companies) } \\
\text { Chestnuts only ( } 8 \text { companies) }\end{array}$ \\
\hline Size of planted area (approximate) & $\begin{array}{l}\text { Between } 1 \text { and } 5 \text { ha ( } 23 \text { companies }) \\
\text { Between } 6 \text { and } 10 \text { ha ( } 15 \text { companies }) \\
\text { Between } 11 \text { and } 15 \text { ha ( } 4 \text { companies }) \\
\text { More than } 16 \text { ha ( } 3 \text { companies) }\end{array}$ \\
\hline Primary customer (main business) & $\begin{array}{l}\text { Cocajupi ( } 40 \text { companies }) \\
\text { Local markets ( } 2 \text { companies }) \\
\text { Intermediators ( } 3 \text { companies })\end{array}$ \\
\hline Main partner in the supply chain of cashew nuts (main business) & $\begin{array}{l}\text { Cocajupi ( } 43 \text { companies) } \\
\text { Without a partnership ( } 2 \text { companies) }\end{array}$ \\
\hline
\end{tabular}

\subsection{Data Collection}

To collect data from the research companies, a survey was used involving three parts. The first aimed to define the profile of the respondents, the second aimed to gain information on the implementation's level of collaboration initiatives in companies from the cashew SC, and the third aimed to collect economic, social, and environmental indicators of sustainability to assess the sustainability behavior of the cashew SC companies. The questionnaire was pre-tested with academics and improved upon attending to their suggestions.

The time-line of the field work was from December 2017 to March 2018 and followed different stages. In the first stage, we tried to make the interviews personal by visiting local farms. This procedure was unsuccessful because of the difficult access to farms (sometimes the use of 4 by 4 cars was required) and the production period. The production period limited the contributions of some farmers who often had to stop their activities to answer the questions. Thus, we conducted most of the interviews via phone [109] and during some of the cooperative's regular meetings.

From the 200 farmer members of the cooperative, 54 were contacted and accepted to collaborate with the survey. After the refinement, nine questionnaires were excluded due to inconsistent data. Therefore, for this research, a sample of 45 participants were used, representing $22.5 \%$ of the 200 farmers that belong to the Cooperative of Cashews in the Piauí state. The convenience sampling process was chosen for this work because it is the best process for surveying with a low availability of respondents. In this type of research, a sample result above $20 \%$ is considered good [110]. 
The questionnaire was also tested to confirm its reliability. Cronbach's $\alpha$ is often used to determine the reliability of constructs [111]. Hair et al. [110] argue that the closer the value of the reliability is to 1.00 , the more reliable the result. The values of reliability that are less than 0.7 are assumed to be weak, while values in the range of 0.70 or higher are acceptable. For instance, the reliability values for the collaboration initiatives were 0.930 regarding the nine items. The results provided support for the development of in-depth analysis to cover the hypotheses.

\subsection{Data Analysis Methods}

To verify and test the different research hypotheses that are suggested in this study and supported in the literature review, a set of statistical methods were performed. To verify the hypotheses, H1a and $\mathrm{H} 1 \mathrm{~b}$, which are related to the collaboration initiatives with high level of implementation by companies from the cashew industry, descriptive statistics were used. To test the hypothesis, H3, which intends to analyze the influence of the size of companies from the cashew industry on the implementation level of collaboration initiatives, the Kruskal-Wallis test was used. The same statistical analysis was performed to test the hypothesis, $\mathrm{H} 4$ (the farm areas of companies that belong to the cashew supply chain influence the indicators of sustainability of the companies that belong to the cashew SC). The non-parametric Kruskal-Wallis test was used because of the small sample size, the homogeneity of variance, and the normality assumptions were violated, not allowing the use of the one-way analysis of variance (ANOVA) [97].

\section{Results}

In this section the main results from the analysis of the data and the statistical outputs are presented and described.

\subsection{Collaboration Initiatives Implemented by Companies from the Cashew SC}

This section aims to analyze the collaboration initiatives implemented by the cashew producers. As seen in Figure 2, all the research farms have implemented a collaboration initiative to some degree.

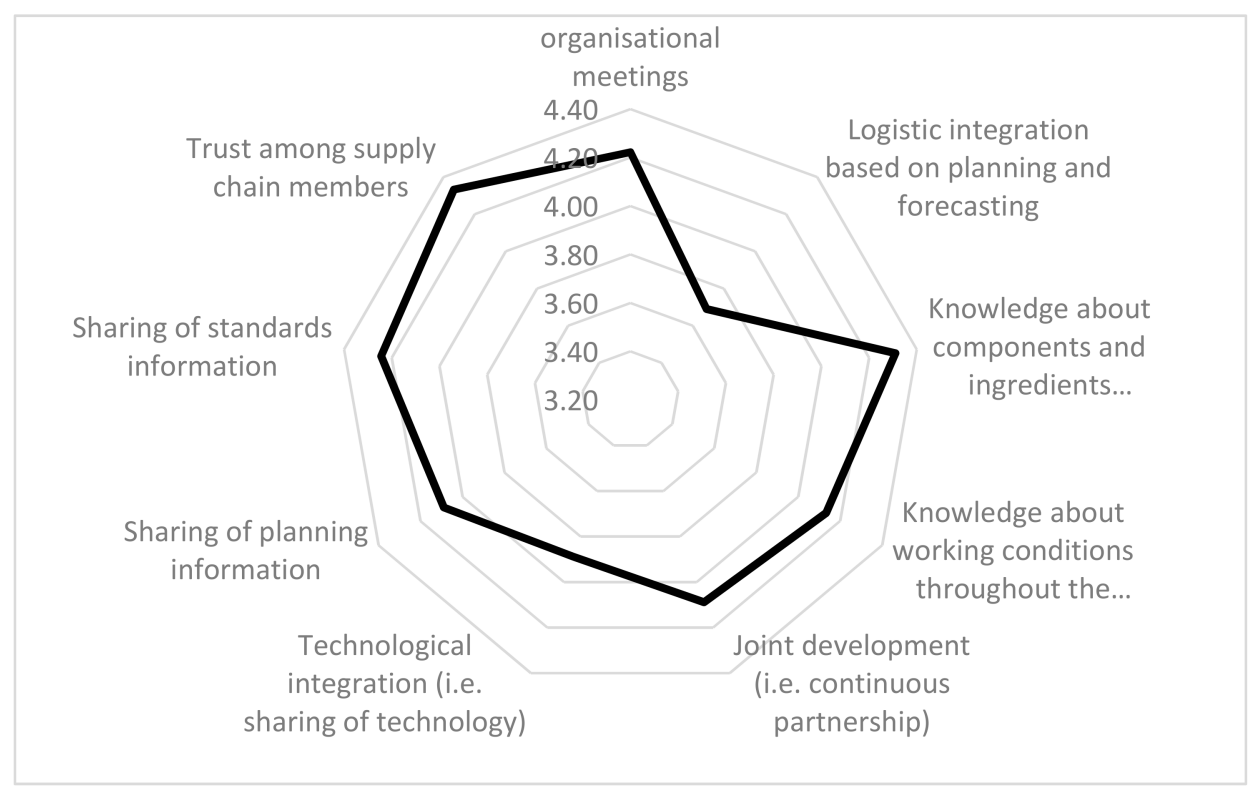

Figure 2. Collaboration initiatives: Average scores. 
In Figure 2, the collaboration initiative with the highest level of implementation among the research companies is the "trust among supply chain members". Additionally, the "regular inter-organizational meetings", the "knowledge about components and ingredients throughout the supply chain", and the "sharing of standards information" initiatives are also implemented by a considerable number of companies. The collaboration initiatives that are not implemented by many companies are the "logistic integration based on planning and forecasting" and the "technological integration" (i.e., sharing of technology). These last initiatives are more suitable to complex SCs [78], since it is necessary to observe a dynamic relationship among SC members not related to cashew production.

This analysis makes it possible to verify that $\mathrm{H} 1 \mathrm{a}$ and $\mathrm{H} 1 \mathrm{~b}$ are aligned with the literature, since Dania et al. [7] state that trust and sharing are the most important collaboration initiatives for the sustainability of the agri-food SC. The same arguments are observed in Panahifar et al. [16], about enablers of collaboration. Thus, the results confirm both "trust among supply chain members" and the "sharing of standards information" as elements that should be observed as a first step in developing sustainable collaboration.

Another analysis was performed to gain a deeper understanding about the influence of the companies' size $(\mathrm{H} 2)$ on the implementation levels of the collaboration initiatives with the main partner in the cashew SC. To perform this analysis, the non-parametric test Kruskal-Wallis was computed (Table 3).

Table 3. Kruskal-Wallis test for $\mathrm{H} 2$.

\begin{tabular}{lcc}
\hline & Pearson's Chi-Squared & Sig. \\
\hline Regular inter-organizational meetings & 5.203 & 0.158 \\
Logistic integration based on planning and forecasting & 0.699 & 0.873 \\
Knowledge of components and ingredients throughout the supply & 3.654 & 0.301 \\
chain & 6.024 & 0.110 \\
Knowledge of working conditions throughout the supply chain & 3.724 & 0.293 \\
Joint development & 3.778 & 0.286 \\
Technological integration & 2.128 & 0.546 \\
Sharing of planning information & 5.656 & 0.130 \\
Sharing of standards information & 4.176 & 0.243 \\
Trust among supply chain members & & \\
a. Kruskal Wallis test; b. Grouping variable: Relative employment & & \\
\hline
\end{tabular}

Note: Significant for a significance level of $10 \%$.

The influence of the company size (relative employment) on the level of implementation of collaboration initiatives is not considerable. That is, the size of companies does not explain the different levels of collaboration initiatives implemented by companies from the cashew SC. This result can be explained by the fact that all the research farms are very small; $93.4 \%$ are micro companies with less than ten employees and only $2.2 \%$ of them have more than 16 employees, according to the European Commission (http:/ / ec.europa.eu/growth/smes/business-friendly-environment/sme-definition_en) (Figure 3). Hence, there was not a significant difference between the farms in terms of size, which can justify the small influence of this factor on the implementation level of collaboration initiatives.

These results demonstrate that collaborative initiatives developed by the companies that belong to the cashew SC are mostly related to how they interact with other members. To advance our analysis, sustainability elements should also be considered in this process. 


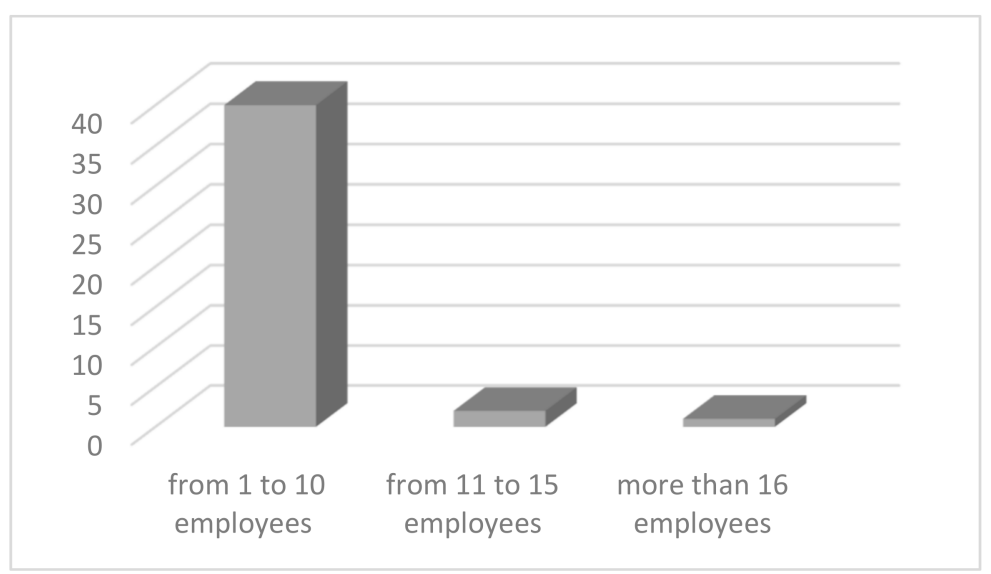

Figure 3. Relative employment among companies that belong to the cashew supply chain.

\subsection{Sustainability of the Cashew Supply Chain}

The traditional perspective of analyzing sustainability is based on the triple bottom line [112]. Hence, in this section, the social, environmental, and economic sustainability behavior of the research companies will be analyzed. With regards to social sustainability, and as can be observed in Figure 4, most of the research' farms attend between six and eight meetings per year to share their knowledge and are concerned about production aspects with other producers, which is aligned with the expected cooperative behavior. However, they do not have a regular relationship with local institutions.

As presented in the Figure 4, social inclusion reflects a nonexistence of any kind of prejudgment. All kinds of people can work in cashew plantations, including women, people with different ethnicities, and young people. In this study, the farms from the cashew SC include at least one young producer, woman, or employee with a different religion. The companies that belong to the cashew SC frequently share their decisions and choices with their partners in the SC and most of them share that information more than four times per year. The impact that the production of cashews has on the standard of living in the local agricultural and rural communities is not significant, since most people do not have enough income to buy equipment, having only one piece of equipment (a tractor).

With regards to the environmental behavior of the companies that belong to the cashew SC (Figure 5), most of them (88.8\%) use rainwater to irrigate the plantations. Concerning the energy used in the farms to support the plantations and the production of cashew juice, most of the companies $(54 \%)$ do not use fossil fuels as energy source. Considering packaging materials, reusable boxes are used by $75.5 \%$ of the research companies and plastic bags by only $24 \%$. The main issue in the environmental field is the use of pesticides in plantations. The companies that belong to the cashew SC are environmental friendly in regards to this issue, since $84.4 \%$ of them do not use pesticides. From the research sample, only seven companies recognize the use of pesticides in their plantations.

Attending to Figure 5, we can see that some practices implemented by farms have a negative impact on the environment, which represents a concern. Attending to the economic sustainability (Figure 6) and focusing on the level of employment, most of the farms (62.2\%) represent micro companies between one and five employees. The "self-sufficient" indicator was not applicable in this research, since, in the region where companies are located, the production is based on calcareous and hydrogel, which are produced in Brazil. Another economic indicator used in this research was the "optimum utilization of the factors of production", represented by the quantity of equipment used. This indicator was analyzed in terms of the quantity of agricultural tractors that support the plantations. Since most of the research companies are small, the results are expected, with $87 \%$ of the respondents having only one tractor. 


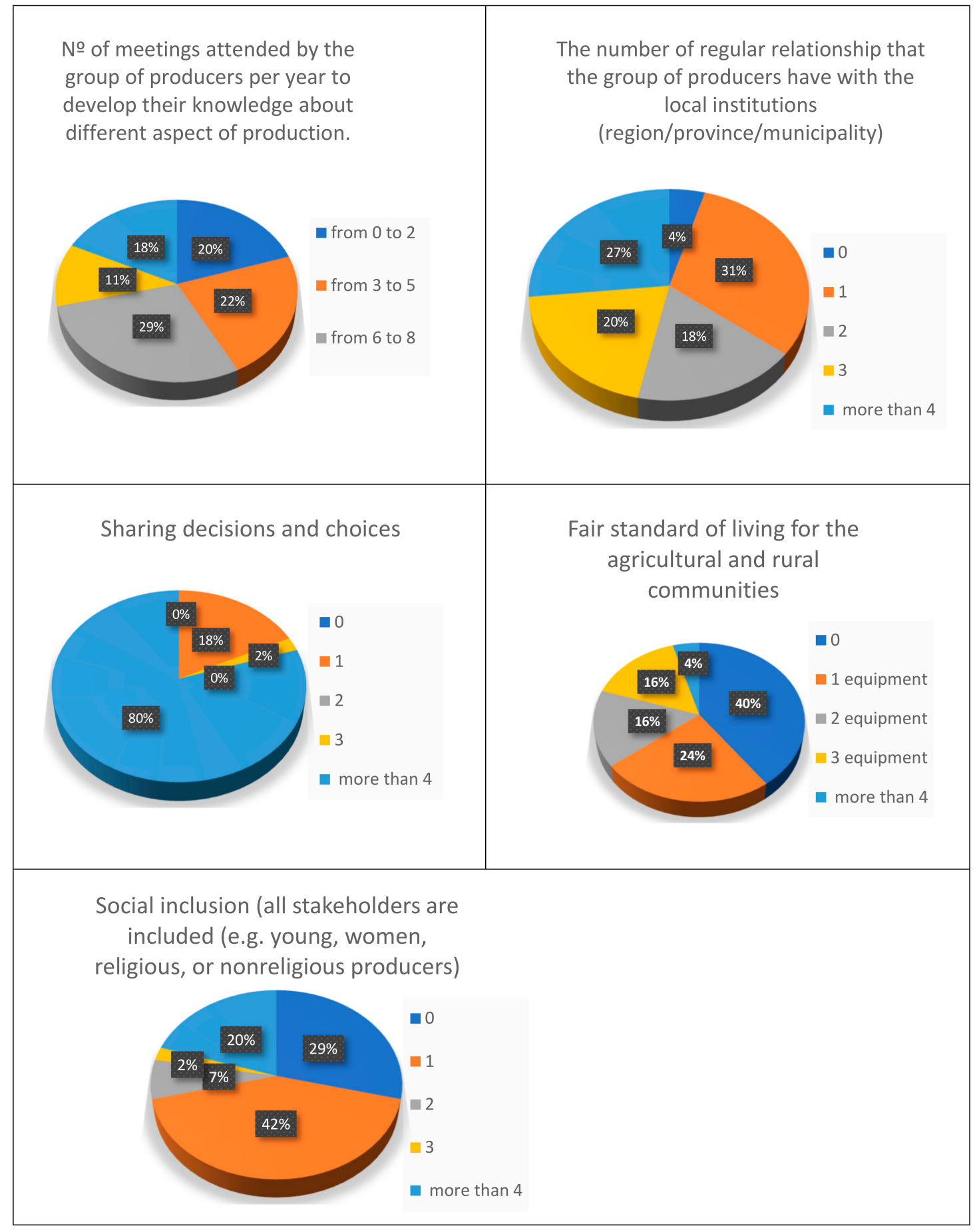

Figure 4. Social sustainability indicators of companies that belong to the cashew SC. 


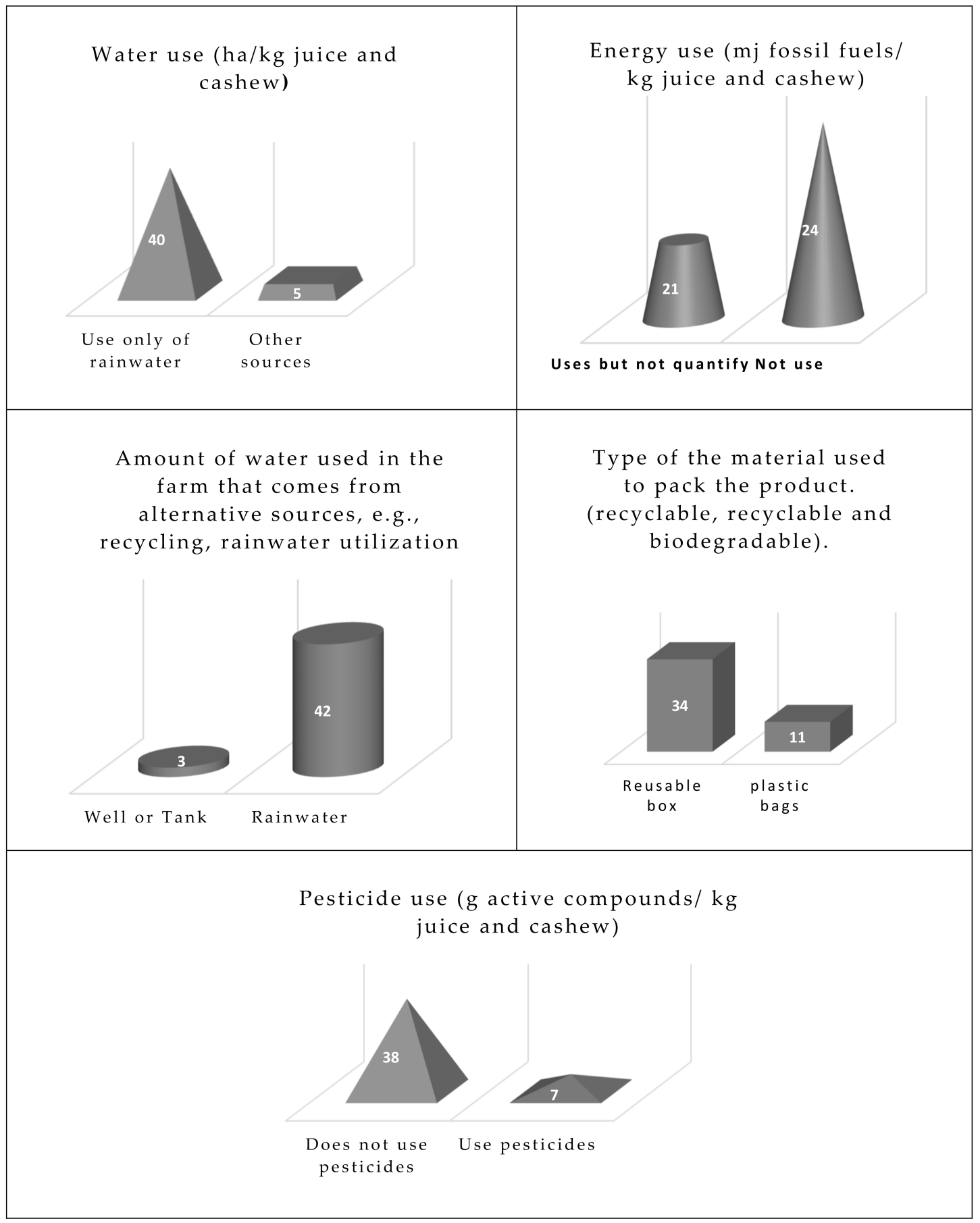

Figure 5. Environmental sustainability indicators of companies that belong to the cashew SC.

The descriptive analysis performed above makes it possible to state that the companies from the cashew SC have some sustainable behavior once some social, environmental, and economic indicators of sustainability are representative. Another interesting issue to explore is whether the farms' area influences the sustainability behavior of the companies (H3). To explore this issue, the Kruskal-Wallis test (Table 4) was used. Attending to the results of Table 4, it is possible to observe that the influence of the farm area of the companies that belong to the cashew SC on sustainability indicators is only statistically significant for two indicators: One belonging to the social dimension of sustainability, "Sharing decisions and choices by year", and the other to the economic dimension, "Relative employment". 


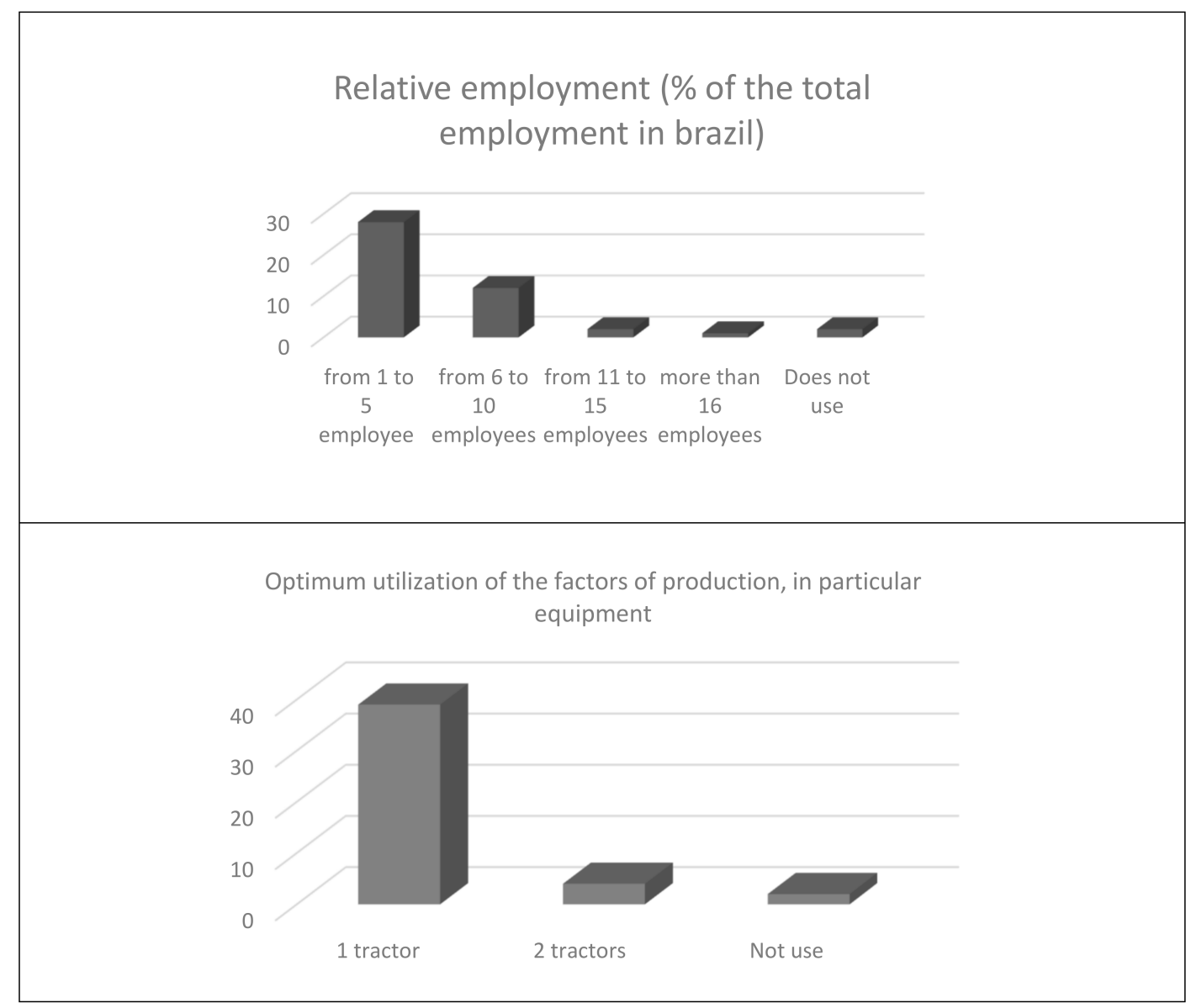

Figure 6. Economic sustainability indicators of companies that belong to the cashew SC.

Attending to the results of the Table 4 it is possible to state that the farms' area does not represent a significant influence on the social, environmental, and economic sustainability indicators of the companies from the cashew SC. In only two of the sustainability indicators did the farms' area have a statistically significance influence, which makes it possible to conclude that $\mathrm{H} 3$ is not verified in this study.

Table 4. Kruskal-Wallis test for H3.

\begin{tabular}{lcc}
\hline \multicolumn{1}{c}{ Sustainability Indicators } & Pearson's Chi-Squared & Sig. \\
\hline Number of meetings attended by the group of producers per year to develop their & 5.375 & 0.146 \\
knowledge about different aspects of production & 4.296 & 0.231 \\
Number of regular relationships that the group of producers have with local institutions & 1.404 & 0.704 \\
Social inclusion & 15.930 & $0.001^{*}$ \\
Sharing decisions and choices by year & 0.798 & 0.850 \\
Fair standard of living for agricultural and rural communities & 2.862 & 0.413 \\
Land use & 1.390 & 0.708 \\
Energy use & 1.971 & 0.579 \\
Amount of water used in the farm that comes from alternative sources & 1.026 & 0.795 \\
Type of material used to pack the product & 4.728 & 0.193 \\
Pesticide use & 15.368 & $0.002^{*}$ \\
Relative employment & 1.514 & 0.679 \\
Optimum utilization of the factors of production & & \\
a. Kruskal Wallis test; b. Grouping variable: Farm' area & & \\
\hline
\end{tabular}

* Significant for a significance level of $10 \%$. 


\subsection{The Relationship Between Collaboration Initiatives and the Sustainability of the Cashew SC}

The analysis performed in this section aims to explore the types of relationships that exist between the implementation level of the collaboration initiative and the social, environmental, and economic sustainability indicators of the cashew supply chain (H4). Spearman's correlation (rs) was used (Table 5). As can be seen in Table 4, some of the relationships between collaboration initiatives and social sustainability indicators are very weak. These include:

- The regular inter-organizational meetings/number of meetings attended by the group of producers per year to develop their knowledge about different aspects of production;

- logistic integration based on planning and forecasting/social inclusion; and

- joint development/social inclusion.

Weak relations include:

- Logistic integration based on planning and forecasting/sharing decisions and choices by year; and

- sharing of planning information/fair standard of living for agricultural and rural communities.

Moderate relations include:

- Regular inter-organizational meetings/sharing decisions and choices by year;

- knowledge about components and ingredients throughout the supply chain/fair standard of living for agricultural and rural communities; and

- knowledge about working conditions throughout the supply chain/sharing decisions and choices by year.

According to the same table, it is also possible to identify some relationships that are negative; that is, the higher the level of implementation of some collaboration initiatives, the worse the sustainability indicators are. Such relationships include:

- Logistic integration based on planning and forecasting/social inclusion;

- knowledge about working conditions throughout the supply chain/social inclusion; and

- sharing of planning information/number of regular relationships that the group of producers have with the local institutions. However, these values are very insignificant.

Table 5. The relationship between the implementation level of collaboration initiatives and the social sustainability indicators of the cashew SC (Spearman's correlation [-rs]).

\begin{tabular}{cccccc}
\hline Collaboration Initiatives & \multicolumn{4}{c}{ Social Sustainability Indicators } \\
\cline { 2 - 6 } & $\mathbf{( 1 )}$ & $\mathbf{( 2 )}$ & $\mathbf{( 3 )}$ & $\mathbf{( 4 )}$ & $\mathbf{( 5 )}$ \\
\hline Regular inter-organizational meetings & 0.101 & 0.101 & 0.055 & 0.400 & 0.270 \\
Logistic integration based on planning and forecasting & 0.000 & 0.000 & -0.005 & $0.351^{*}$ & 0.265 \\
Knowledge about components and ingredients throughout the supply chain & 0.160 & 0.160 & 0.093 & 0.284 & 0.429 \\
Knowledge about working conditions throughout the supply chain & 0.205 & 0.205 & -0.137 & 0.486 & 0.315 \\
Joint development & 0.173 & 0.173 & 0.074 & 0.460 & 0.252 \\
Technological integration & -0.041 & -0.041 & 0.031 & 0.376 & 0.240 \\
Sharing of planning information & -0.044 & -0.044 & -0.042 & 0.465 & 0.251 \\
Sharing of standards information & 0.143 & 0.143 & 0.006 & 0.658 & 0.128 \\
Trust among supply chain members. & 0.204 & 0.204 & 0.212 & 0.403 & 0.363 \\
\hline
\end{tabular}

Note: * Significant for a significant level of $10 \%$ (1) Number of meetings attended by the group of producers per year to develop their knowledge about different aspects of production; (2) Number of regular relationships that the group of producers have with local institutions; (3) Social inclusion; (4) Sharing decisions and choices by year; (5) Fair standard of living for agricultural and rural communities.

The relationships between the level of implementation of collaboration initiatives and the environmental sustainability indicators are also explored using Spearman's correlation coefficient. As outlined in Table 6, most of the relationships are very weak. These include: 
- Regular inter-organizational meetings/land use;

- logistic integration based on planning and forecasting/amount of water used in the farm that comes from alternative sources; and

- knowledge about components and ingredients throughout the supply chain/pesticide use; and technological integration/amount of water used in the farm that comes from alternative sources.

Weak relationships include:

- Regular inter-organizational meetings/energy use;

- knowledge about components and ingredients throughout the supply chain/energy use;

- joint development/energy use; and

- sharing of standards information/energy use.

Many of the relationships between the level of implementation of collaboration initiatives and the environmental sustainability indicators are very weak or weak. The "Energy use" indicator seems to be the only indicator that is positively influenced by collaboration initiatives, since most of the values of the Spearman correlation coefficient are negative. For example, the collaboration initiative, "Sharing of standards information", could be illustrated in terms of, for example, the timely information about the production level of SC partners. This strategic information will make it possible to mitigate the bullwhip effect and the elimination of many wastes associated to over-production that results in stocks' holding across the SC partners even in the agri-food business. This collaborative initiative will also result in a more efficient use of energy and, consequently, more sustainable companies.

Another collaborative practice that influences energy use is the "Joint development". In all tiers of the food supply chain, most energy used is derived from fossil fuels. Energy is used across the whole food supply chain, from the manufacture of agricultural inputs, such as fertilizers, for irrigation, through to crops and livestock production, and processing and packaging [113]. If companies in the food SC implement collaboration initiatives in a joint development approach to projects to improve the efficiency of some of these activities the energy use will decrease.

Table 6. The relationship between the collaboration initiatives and the environmental sustainability indicators of the cashew SC (Spearman's correlation [-rs]).

\begin{tabular}{cccccc}
\hline Collaboration Initiatives & \multicolumn{4}{c}{ Environmental Sustainability Indicators } \\
\cline { 2 - 6 } & $\mathbf{( 1 )}$ & $\mathbf{( 2 )}$ & $\mathbf{1 3}$ & $\mathbf{( 4 )}$ & $\mathbf{1 5}$ \\
\hline Regular inter-organizational meetings & -0.051 & -0.215 & 0.093 & 0.085 & 0.013 \\
Logistic integration based on planning and forecasting & 0.012 & -0.144 & 0.008 & -0.189 & -0.154 \\
Knowledge about components and ingredients throughout the supply chain & 0.133 & -0.265 & 0.107 & -0.141 & -0.030 \\
Knowledge about working conditions throughout the supply chain & -0.007 & -0.091 & 0.008 & -0.096 & -0.096 \\
Joint development & -0.007 & -0.319 & 0.108 & -0.137 & 0.050 \\
Technological integration & 0.035 & -0.272 & -0.003 & -0.216 & 0.023 \\
Sharing of planning information & -0.009 & -0.111 & -0.014 & -0.228 & -0.040 \\
Sharing of standards information & -0.010 & -0.372 & 0.038 & 0.138 & 0.003 \\
Trust among supply chain members. & 0.081 & 0.104 & 0.216 & 0.148 & 0.228 \\
\hline
\end{tabular}

Notes: It was decided not to consider the "water use" environmental indicator because only one type of response was observed. (1) Land use; (2) Energy use; (3) Amount of water used in the farm that comes from alternative sources; (4) Type of material used to pack the product; (5) Pesticide use.

Concerning the relation between collaboration initiatives and "water used from alternative sources" in the agri-food SC there are some real examples. It is known that farmers, generally, aim to make optimal use of existing water supplies as it can be costly and complex to develop new resources. Better use of water can be achieved by adopting innovative technologies and better on-farm water management. However, alongside this it is necessary to consider the development of new resources, such as farm reservoirs, to secure rainwater supplies, which, in some cases, are shared by several farmers [114].

Another example is related to the use of pesticides. The International Code of Conduct on the Distribution and Use of Pesticides [115] (FAO, 2005) defends that pesticide management should 
be considered as part of chemical management, as well as of sustainable agricultural development. This means that collaboration and information exchange between various entities, in particular those involved in agriculture, public health, environment, commerce, and trade, are becoming increasingly important. New stakeholders have also been identified, such as the equipment sellers and food industries, and enhanced cooperation with them is also important. Additionally, the "Type of the material used to pack the product" is another indicator positively influenced by the collaboration initiatives implemented by the companies in the cashew SC.

Most of the relationships between the collaboration initiatives and the economic sustainability (Table 7) are weak; for example:

- Regular inter-organizational meetings/optimum utilization of the factors of production;

- joint development/optimum utilization; and

- sharing of standard information/optimum utilization of the factors of production.

However, a strong relationship exists between the "Logistic integration based on planning and forecasting" and "Relative Employment" ( $r s=0.760)$.

Attending to all the analyses performed in this section, we can conclude that a weak relationship exists between the collaboration initiatives and the indicators associated to the three dimensions of sustainability.

Table 7. The relationship between the collaboration initiatives and the economic sustainability indicators of the cashew SC (Spearman's correlation -rs).

\begin{tabular}{ccc}
\hline Collaboration Initiatives & \multicolumn{2}{c}{ Economic Sustainability Indicators } \\
\cline { 2 - 3 } & $\mathbf{( 1 )}$ & $\mathbf{( 2 )}$ \\
\hline Regular inter-organizational meetings & 0.047 & 0.282 \\
Logistic integration based on planning and forecasting & 0.760 & 0.061 \\
Knowledge about components and ingredients throughout the supply chain & -0.124 & 0.218 \\
Knowledge about working conditions throughout the supply chain & -0.161 & 0.078 \\
Joint development & 0.087 & 0.218 \\
Technological integration & 0.022 & 0.086 \\
Sharing of planning information & -0.041 & 0.047 \\
Sharing of standards information & -0.149 & 0.252 \\
Trust among supply chain members. & 0.080 & 0.039 \\
\hline
\end{tabular}

Note: It was not possible to compute the Spearman correlation using the economic indicator, "Self-sufficient", because it has only one type of response. (1) Relative employment; (2) Optimum utilization of the factors of production.

\section{Discussion}

This paper aims to analyze the influence of collaboration initiatives on sustainability indicators of companies in the cashew SC. A set of hypotheses were proposed based on the literature review, which are intended to analyze the influence of the size of companies and the farms' area on the sustainability indicators of companies and to verify whether the implementation of collaboration initiative influences the social, environmental, and economic sustainability indicators of the companies that belong to the cashew SC.

With regards to the type of collaboration initiatives performed by the research companies, it is verified that the ones with higher levels of implementation are the following: Trust among supply chain members, sharing of standards' information, sharing of planning information, and knowledge about components and ingredients throughout the supply chain. One collaboration initiative that presents a small level of implementation among the cashew companies is the "Logistics integration based on planning and forecasting". According to these results, it is possible to say that the H1a (Trust is a collaboration initiative that has a high level of implementation among companies in the cashew industry) and H1b (Sharing activities is a collaboration initiative that has a high level of implementation among companies in the cashew industry) hypotheses can be verified, since "Trust 
among supply chain members" and the "Sharing of standards information" have the highest levels of implementation.

This result aligns with the work of Dania et al. [7], which highlighted trust and sharing activities as a pattern of collaboration initiatives in the agri-food literature. The work of Beech and Huxham [116] also highlights trust as important for real collaboration. Additionally, "Logistics integration based on planning and forecasting", while implemented on a smaller scale, is also supported in the literature. To Engelseth [117], the linkage between the logistics systems of stakeholders in the agriculture and the food supply chains is rather loose and fragmented. The concept of agricultural and food logistics has been underdeveloped and a more effective and efficient management system is required for food production planning, the physical collection of primary production from fields and homesteads, processing and storage at various levels, handling, packaging, and distribution. Even within individual companies, the vertical and internal integration related to freight and logistics is loose and, therefore, they are both economically and environmentally inefficient and unsustainable [118].

Regarding H2 (There are differences in the level of implementation of collaboration initiatives among companies with different size), it is not verified in this study, since the size of the companies seems to have no influence on the level of collaboration initiatives. This result is not supported in the literature, since Matopoulos et al. [6] and Hubeau et al. [4] argue that the intrinsic structure of the food supply chain, in which companies are different in terms of product characteristics, size, location, and access to technology, affects the collaboration they could establish. This may also occur because of the diverse bargaining power of companies. Contrary to this theory, in our study, the size of companies seems to have no influence on the implementation level of collaboration initiatives because almost all sample companies are very small, with $93.4 \%$ of them representing micro companies. Therefore, the size of companies is not sufficient to justify the differences in the implementation level of collaboration initiatives.

Regarding sustainability, the companies that belong to the cashew SC are better performers in terms of social sustainability indicators, since they are concerned about sharing knowledge of different aspects of production with their SC partners, as well as their decisions and choices. Analyzing their environmental indicators, they use mainly rainwater as an alternative water source, avoid using energy from fossil fuels, use reusable boxes to pack the products, and avoid using pesticides in plantations. The economic indicators, in terms of sustainability, for the companies from the cashew $\mathrm{SC}$ are not so favorable. This is because of the insignificant impact that the companies have on their local communities in terms of wealth creation, which is driven by the small size of the companies and the planted land areas, thus, limiting the utilization of production factors. This is in line with Pinter et al. [119] who defend the promotion of economic growth as an important objective of sustainable development. Also, according to DEFRA [120], there is a concern that the food supply chain in many countries is underperforming in terms of economic output, profitability, incomes, and productivity.

The hypothesis, H4 (The farms' area of companies that belong to the cashew supply chain influence the indicators of sustainability of the companies that belong to the Cashew SC), intends to analyze whether the farms' area influences the sustainability indicators of the companies from the cashew SC. Attending to the results from the companies that belong to our case study, this factor does not have a significant influence, which is not aligned with the literature in some cases. For example, environmentally, and considering a farm with a small area of production, it is easier to control the disruption that could result from a pest outbreak than a large farm [99]. Thus, the negative impacts that could result from this situation on the environment are more controllable. Economically, in a scenario of higher production costs, smaller companies become less profitable, negatively affecting the sustainability of farming [121]. Also, the social dimension of sustainability is positively influenced by the farms' areas. Tisdell [122] defends that the main advantages of smaller farms' areas to social sustainability is the possibility of keeping the intergenerational economic welfare, the existence of human beings indefinitely, and the sustainability of production and economic systems, in terms of their resilience. 
Considering the relationships between the implementation level of collaboration initiatives and the sustainability indicators of the cashew SC (H4: The level of implementation of collaboration initiatives influences some sustainability indicators of the companies from the cashew SC), most of them are weak. Those that present a higher value inside the moderate interval have an rs value between 0.40 and 0.59 and those that present a strong interval have an rs value between 0.60 and 0.79 , as shown in Table 8.

Observing Table 8, it is possible to state that collaboration initiatives do not deeply influence the sustainability indicators of the companies from the cashew SC. Additionally, the sustainability indicators that are more influenced by the collaboration initiatives are the ones that belong to social sustainability, which is reflected by a strong relationship between the "Sharing of standards information" initiative and the social sustainability indicator, "Sharing decisions and choices by year" ( $\mathrm{rs}=0.658)$. Another strong relationship can be identified between the "Logistics integration based on planning and forecasting" initiative and the economic sustainability indicator, "Relative Employment" $(\mathrm{rs}=0.760)$. Moreover, the research sample does not present any significant relationship between the collaboration initiatives and the environmental sustainability indicators.

Table 8. Relationships between the implementation level of collaboration initiatives and the sustainability indicators of the cashew SC (H4), considering the highest Spearman correlation coefficients.

\begin{tabular}{|c|c|c|c|}
\hline $\begin{array}{ll}\text { Collaboration Initiatives } & \text { Sustainability Indicators } \\
\end{array}$ & Social & Environmental & Economic \\
\hline Regular inter-organizational meetings & $\begin{array}{l}\text { Sharing decisions and } \\
\text { choices by year }(0.400)\end{array}$ & & \\
\hline Logistics integration based on planning and forecasting & & & $\begin{array}{l}\text { Relative employment } \\
(0.760)\end{array}$ \\
\hline $\begin{array}{l}\text { Knowledge about components and ingredients } \\
\text { throughout the supply chain }\end{array}$ & $\begin{array}{l}\text { Fair standard of living for } \\
\text { agricultural and rural } \\
\text { communities }(0.429)\end{array}$ & & \\
\hline $\begin{array}{l}\text { Knowledge about working conditions throughout the } \\
\text { supply chain }\end{array}$ & $\begin{array}{l}\text { Sharing decisions and } \\
\text { choices yearly }(0.486)\end{array}$ & & \\
\hline Joint development & $\begin{array}{l}\text { Sharing decisions and } \\
\text { choices yearly }(0.460)\end{array}$ & & \\
\hline Sharing of planning information & $\begin{array}{l}\text { Sharing decisions and } \\
\text { choices yearly }(0.465)\end{array}$ & & \\
\hline Sharing of standards information & $\begin{array}{l}\text { Sharing decisions and } \\
\text { choices yearly }(0.658)\end{array}$ & & \\
\hline Trust among supply chain members & $\begin{array}{l}\text { Sharing decisions and } \\
\text { choices yearly }(0.403)\end{array}$ & & \\
\hline
\end{tabular}

These results are not very surprising to the literature, since many debates on the relationship between sustainability performance and collaboration have been inconclusive [5]. Also, some authors [73] state that collaboration does not directly impact sustainability. According to them, sustainability can only relate to collaboration initiatives if there are external partnerships and if the supply chain members incorporate sustainability internally in their practices before spreading it to the entire supply chain. León-Bravo et al. [5] argue that the degree to which collaboration in sustainability occurs depends on the stage, the company size and power, and the level of vertical integration. Beyond this, Hubeau et al. [4] also defend that the influence of collaboration on sustainability depends on a set of factors, such as: Transaction characteristics, coordination mechanisms, length of relationships, type of relationships, interaction between SC partners, and motivation.

As these factors were not explored in this study, they could be responsible for the lack of influence of collaboration initiatives on the sustainability indicators of the companies from the cashew SC. Based on these results, we can say that $\mathrm{H} 4$ is not verified, since not all indicators associated to the three dimensions of sustainability are influenced by the collaboration initiatives. The collaboration initiatives 
focused on in this work mainly influence the social indicators of sustainability of the companies that belong to the cashew SC.

\section{Conclusions}

This study was intended to contribute to the current knowledge related to both research themes by analyzing the influence of collaboration initiatives on sustainability. The findings revealed that trust and sharing information are key factors in studying this topic, since they influence the development of several social indicators. Also, with this research and for the research companies, the size does not have a significant influence on the implementation level of collaboration initiatives. This could be related to the cooperative environment around these farms, which can facilitate the empowerment of small companies in the market.

Based on the results, and considering the focused social, environmental, and economic indicators, we can say that the companies that belong to the cashew SC show some sustainable behavior. Also, the farms' area of the companies that belong to our case study does not present an influence that is statistically significant on their sustainable indicators. The economic dimension needs to receive more attention, since the literature on SCS is usually related to profitability and growth, which sometimes do not consider local development and its influence on sustainability behaviors. Finally, the results point out that there is not a relationship between the collaboration initiatives and all the indicators associated to the three dimensions of sustainability. This relationship is more visible in the social indicators. Therefore, the collaboration initiatives focused on in this study mainly influence the social behavior of the research companies. This issue requires an in-depth analysis from the academy.

Managerial implications: In this study, a set of collaboration initiatives and social, environmental, and economic sustainability indicators were suggested to the cashew industry, which represent an important contribution to the professionals in this sector who wish to adopt collaboration initiatives and a more sustainable behavior. Also, the drivers for a better collaboration in terms of sustainability were identified to justify the weak relationships between the implementation levels of collaboration initiatives and the performance of sustainability indicators of the companies in the cashew SC. Therefore, companies that wish to adopt collaboration initiatives to become more sustainable should, firstly, observe these drivers, which include stage, company size and power, and the level of vertical integration.

Limitations and Future Research: The main limitations of the study concern the homogeneity of the companies used in the study regarding size, product typology, and location, as well as the small sample. The major limitation of this study is the sampling, which does not make possible their generalization to other agri-food contexts or even other cashew SCs, but the "cashew farmers in Northern Brazil". This issue may be the main responsible for our results.

Also, it is important to consider the limitations of a set of sustainability indicators that represent how the agri-food industry can develop sustainability behavior. For this end, we grouped several contributions and created a list of indicators that can facilitate future research to improve the knowledge on the sustainability topic. Furthermore, for future research, integrating the Resource Dependence Theory and the Social Network Theory to explain collaboration for sustainability in the supply chain is suggested [123]. Also, it is important to develop research pertaining to the sustainability indicators from the region and how they can facilitate or be related to collaboration initiatives. Developing the same research qualitatively could be valuable in discovering the reasons behind local companies' behaviors regarding sustainability.

Author Contributions: The conceptualization of the research and analysis of results was performed by S.G.A., the design of the Methodology was developed by M.E.S., the data collection by G.P.D. and the supervisions and writing review and edition by J.C.O.M. Also, the literature review on collaboration initiatives was performed by M.E.S. and G.P.D. and the one on sustainability was performed by S.G.A. and J.C.O.M. 
Funding: This research was funded by CEFAGE-UBI from FCT, Portugal, FEDER/COMPETE 2020, through grant number UID/ECO/04007/2013 (POCI-01-0145-FEDER-007659), and by Edson Queiroz Foundation through grant number DPDI 30/17.

Conflicts of Interest: The authors declare no conflict of interest.

\section{References}

1. Ding, H.; Huang, H.; Tang, O. Sustainable supply chain collaboration with outsourcing pollutant-reduction service in power industry. J. Clean. Prod. 2018, 186, 215-228. [CrossRef]

2. Silva, M.E.; Oliveira, A.P.; Gómez, C.R. Can collaboration between firms and stakeholders stimulate sustainable consumption? Discussing roles in the Brazilian electricity sector. J. Clean. Prod. 2013, 47, $236-244$. [CrossRef]

3. Vachon, S.; Klassen, R.D. Environmental management and manufacturing performance: The role of collaboration in the supply chain. Int. J. Prod. Econ. 2008, 111, 299-315. [CrossRef]

4. Hubeau, M.; Marchand, F.; Van Huylenbroeck, G. Sustainability experiments in the agri-food system: Uncovering the factors of new governance and collaboration success. Sustainability 2017, 9, 1027. [CrossRef]

5. León-Bravo, V.; Caniato, F.F.; Caridi, M.; Johnsen, T. Collaboration for Sustainability in the Food Supply Chain: A Multi-Stage Study in Italy. Sustainability 2017, 9, 1253. [CrossRef]

6. Matopoulos, A.; Vlachopoulou, M.; Manthou, V.; Manos, B. A conceptual framework for supply chain collaboration: Empirical evidence from the agri-food industry. Supply Chain Manag. Int. J. 2007, 8, 177-186. [CrossRef]

7. Dania, W.A.P.; Xing, K.; Amer, Y. Collaboration behavioural factors for sustainable agri-food supply chains: A systematic review. J. Clean. Prod. 2018, 186, 851-864. [CrossRef]

8. Lu, L.; Qi, X.; Liu, Z. On the cooperation of recycling Operations. Eur. J. Oper. Res. 2014, 233, 349-358. [CrossRef]

9. Soylu, A.; Oruç, C.; Turkay, M.; Fujita, K.; Asakura, T. Synergy analysis of collaborative supply chain management in energy systems using multi-period MILP. Eur. J. Oper. Res. 2006, 174, 387-403. [CrossRef]

10. Schiefer, S.; Gonzalez, C.; Flanigan, S. More than just a factor in transition processes? The role of collaboration in agriculture. In Transition Pathways towards Sustainability in Agriculture: Case Studies from Europe; Sutherland, L.A., Darnhofer, I., Wilson, G.A., Zagata, L., Eds.; CPI Group (UK) Ltd.: Croydon, UK, 2015; p. 229.

11. Erkuş-Öztürk, H.; Eraydın, A. Environmental governance for sustainable tourism development: Collaborative networks and organisation building in the Antalya tourism region. Tour. Manag. 2010, 31, 113-124. [CrossRef]

12. Sustainability Pathways. Available online: http://www.fao.org/nr/sustainability/food-loss-and-waste/en/ (accessed on 28 May 2018).

13. Chen, L.; Zhao, X.; Tang, O.; Price, L.; Zhang, S.; Zhu, W. Supply chain collaboration for sustainability: A literature review and future research agenda. Int. J. Prod. Econ. 2017, 194, 73-87. [CrossRef]

14. Cao, M.; Zhang, Q. Supply chain collaboration: Impact on collaborative advantage and firm performance. J. Oper. Manag. 2011, 29, 163-180. [CrossRef]

15. Chen, I.J.; Paulraj, A. Towards a theory of supply chain management: The constructs and measurements. J. Oper. Manag. 2004, 22, 119-150. [CrossRef]

16. Panahifar, F.; Byrne, P.J.; Salam, M.A.; Heavey, C. Supply chain collaboration and firm performance: The critical role of information sharing and trust. J. Enterp. Inf. Manag. 2018, 31. [CrossRef]

17. Candelo, E.; Casalegno, C.; Civera, C.; Mosca, F. Turning Farmers into Business Partners through Value Co-Creation Projects. Insights from the Coffee Supply Chain. Sustainability 2018, 10, 1018. [CrossRef]

18. Mena, S.; de Leede, M.; Baumann, D.; Black, N.; Lindeman, S.; McShane, L. Advancing the business and human rights agenda: Dialogue, empowerment, and constructive engagement. J. Bus. Ethics 2010, 93, 161-188. [CrossRef]

19. PNUD (Programa das Nações Unidas para o Desenvolvimento). Available online: http:/ /www.br.undp. org/content/brazil/pt/home/idh0.html (accessed on 26 May 2018).

20. Vidal, M.F. Situação da Cajucultura Nordestina Após a Seca; Caderno Setorial ETENE; Banco do Nordeste: Fortaleza, Brasil, 2016. 
21. Sethi, S.P. Investing in Socially Responsible Companies is a must for Public Pension Funds-Because there is no Better Alternative. J. Bus. Ethics 2005, 56, 99-129. [CrossRef]

22. Vermeir, I.; Verbeke, W. Sustainable Food Consumption: Exploring the Consumer "Attitude-Behavioral Intention" Gap. J. Agric. Environ. Ethics 2006, 19, 169-194. [CrossRef]

23. Solomon, M. Consumer Behaviour: A European Perspective; Pearson Education: New York, NY, USA, 2010.

24. Tukker, A.; Jensen, B. Environmental impacts of products: A detailed review of studies. J. Ind. Ecol. 2006, 10, 159-182. [CrossRef]

25. Garnett, T. Where are the best opportunities for reducing greenhouse gas emissions in the food system (including the food chain)? Food Policy 2011, 36, 23-32. [CrossRef]

26. A Framework for Indicators for the Economic and European Comission, Social Dimensions of Sustainable Agriculture and Rural Development. 2001. Available online: https://ec.europa.eu/agriculture/publi/ reports/sustain/index_en.pdf (accessed on 2 October 2017).

27. Pullman, M.E.; Maloni, M.J.; Carter, C.R. Food for thought: Social versus environmental sustainability practices and performance outcomes. J. Supply Chain Manag. 2009, 45, 38-54. [CrossRef]

28. Aiking, H.; De Boer, J. Food sustainability: Diverging interpretations. Br. Food J. 2004, 106, 359-365. [CrossRef]

29. Maloni, M.J.; Brown, M.E. Corporate social responsibility in the supply chain: An application in the food industry. J. Bus. Ethics 2006, 68, 35-52. [CrossRef]

30. Smith, B.G. Developing sustainable food supply chains. Proc. R. Soc. Lond. B Biol. Sci. 2008, 363, 849-861. [CrossRef] [PubMed]

31. Osinga, S.A.; Hofstede, G.J. Transparency in the pork supply chain: Comparing China and the Netherlands. In Proceedings of the 99th European Association of Agricultural Economists (EAAE) Seminar Trust and Risk in Business Networks, Bonn, Germany, 8-10 February 2006; pp. 93-102.

32. Roth, A.V.; Tsay, A.A.; Pullman, M.E.; Gray, J.V. Unraveling the food supply chain: Strategic insights from China and the 2007 recalls. J. Supply Chain Manag. 2008, 44, 22-39. [CrossRef]

33. Trienekens, J.H. Agricultural value chains in developing countries: A framework for analysis. Int. Food Agribus. Manag. Rev. 2011, 14, 51-82.

34. Kissinger, M. International trade related food miles-The case of Canada. Food Policy 2012, 37, 171-178. [CrossRef]

35. Yakovleva, N. Measuring the sustainability of the food supply chain: A case study of the UK. J. Environ. Policy Plan. 2007, 9, 75-100. [CrossRef]

36. Jackson, L.E.; Pascual, U.; Hodgkin, T. Utilizing and conserving agrobiodiversity in agricultural landscapes. Agric. Ecosyst. Environ. 2007, 121, 196-210. [CrossRef]

37. Dirzo, R.; Raven, P.H. Global state of biodiversity and loss. Annu. Rev. Environ. Resour. 2003, 28, $137-167$. [CrossRef]

38. Ilbery, B.; Maye, D. Food supply chains and sustainability: Evidence from specialist food producers in the Scottish/English borders. Land Use Policy 2005, 22, 331-344. [CrossRef]

39. Wilson, E.O. The Diversity of Life; Harvard University Press: Cambridge, MA, USA, 1992.

40. Hardt, M.; Negri, A. Impero, II Nuovo Ordine Della Globalizzazione; Rizzoli: Milano, Italy, 2002.

41. Christensen, T.; Olsen, S.B.; Dubgaard, A.; Kaergård, N. Organic farming and multi-criteria decisions: An economic survey. Producing and Reproducing Farming Systems: New Models of Organisation for Sustainable Food Systems of Tomorrow. In Proceedings of the 10th European IFSA Symposium International Farming Systems Association-Europe Group, Aarhus, Denmark, 1-4 July 2012.

42. Glenn, N.A.; Pannell, D.J. The economics and application of sustainability indi-cators in agriculture. In $42 n d$ Annual Conference of the Australian Agricultural and Resource Economics Society; University of New England: Armidale, Australia, 1998; pp. 19-21.

43. Bélanger, V.; Vanasse, A.; Parent, D.; Allard, G.; Pellerin, D. Development of agri-environmental indicators to assess dairy farm sustainability in Quebec Eastern Canada. Ecol. Indic. 2012, 23, 421-430. [CrossRef]

44. Bockstaller, C.; Guichard, L.; Keichinger, O.; Girardin, P.; Galan, M.-B.; Gaillard, G. Comparison of methods to assess the sustainability of agricultural systems: A review. Sustain. Agric. 2009, 29, 223-235.

45. Rametsteiner, E.; Pülzl, H.; Olsson, J.; Frederiksen, P. Sustainability indicator development-Science or political negotiation? Ecol. Indic. 2011, 11, 61-70. [CrossRef] 
46. Singha, R.; Murty, H.; Guptac, S.; Dikshit, A. An overview of sustainability assessment methodologies. Ecol. Indic. 2012, 15, 281-299. [CrossRef]

47. Roy, R.; Chan, N. An assessment of agricultural sustainability indicators in Bangladesh: Review and synthesis. Environmentalist 2012, 32, 99-110. [CrossRef]

48. Van Passel, S.; Meul, M. Multilevel and multi-user sustainability assessment of farming systems. Environ. Impact Assess. 2012, 32, 170-180. [CrossRef]

49. Dantsis, N.L.; Douma, T.; Giourga, C.; Loumou, C.; Polychronaki, E.A. A method-ological approach to assess and compare the sustainability level of agriculturalplant production systems. Ecol. Indic. 2010, 10, 256-263. [CrossRef]

50. De Boer, I.; Cornelissen, A. A method using sustainability indicators to com-pare conventional and animal-friendly egg production systems. Poult. Sci. 2002, 81, 173-181. [CrossRef] [PubMed]

51. Dillon, E.J.; Hennessy, T.; Hynes, S. Assessing the sustainability of Irish agri-culture. Int. J. Agric. Sustain. 2010, 8, 131-147. [CrossRef]

52. Indicators of Sustainable Development: Guidelines and Methodologies; United Nations: New York, NY, USA, 2007.

53. Gómez-Limón, J.A.; Sanchez-Fernandez, G. Empirical evaluation of agri-cultural sustainability using composite indicators. Ecol. Econ. 2010, 69, 1062-1075. [CrossRef]

54. Kulig, A.; Kolfoort, H.; Hoekstra, R. Welfare Measurement in a NationalAccounting Framework; CBS Statistics: The Hague, The Netherlands, 2007.

55. Indicators to Measure Decoupling of Environmental Pressure from Economic Growth; SG/SD; OECD: Paris, France, 2002.

56. Wiedmann, T.; Minx, J. A Definition of 'Carbon Footprint'; Research \& Consulting; Nova Science Publishers: Hauppauge, NY, USA, 2007.

57. Hoekstra, A.Y.; Chapagain, A.; Martinez-Aldaya, M.; Mekomen, M. Water Footprint Manual: State of the Art 2009; Water Footprint Network: Enschede, The Netherlands, 2009.

58. Gertsakis, J.; Lewis, H. Sustainability and the Waste Management Hierarchy: A Discussion Paper; EcoRecycle Victoria: Melbourne, Australia, 2003.

59. Global Reporting Initiative. G4 Sustainability Reporting Guidelines; Reporting Principles and Disclosures, Hämtad. Global Reporting Initiative: Amsterdam, The Netherlands, 2013. Available online: https://www. globalreporting.org/information/g4/Pages/default.aspx (accessed on 24 May 2018).

60. BASF AgBalance. 2015. Available online: http://www.agro.basf.com/agr/AP-internet/en/content/ sustainability/measuring_sustainability/agbalance/index (accessed on 15 May 2018).

61. United Nations Food and Agriculture Organization. Livestock Environmental Assessment and Performance (LEAP) Partnership. 2015. Available online: http://www.fao.org/partnerships/leap/en/ (accessed on 15 May 2018).

62. British Standards Institute. PAS 2015. Available online: http://shop.bsigroup.com/en/forms/PASs/PAS2050/ (accessed on 14 June 2018).

63. Stewardship Index for Specialty Crops. 2015. Available online: http://www.stewardshipindex.org/ (accessed on 15 May 2018).

64. Kuneman, G.; Fellus, E.; Ywema, P.; Elferink, E.; van der Wal, E.; can Vliet, J.; Terryn, L.; Lindsay, B.; van der Schans, F. Sustainability Performance Assessment Version 2.0. In Towards Consistent Measurement of Sustainability at Farm Level; SAI Platform: Etterbeek, Belgium, 2014.

65. Peano, C.; Migliorini, P.; Sottile, F. A methodology for the sustainability assessment of agri-food systems: An application to the Slow Food Presidia project. Ecol. Soc. 2014, 19, 24. [CrossRef]

66. Food and Agriculture Organization of the United Nations (FAO). Multiple Use of Water. 2011. Available online: http:/ / www.fao.org/nr/water/topics_irrig_mus.html (accessed on 26 May 2018).

67. Van Asselt, E.D.; van Bussel, L.G.J.; van der Voet, H.; van der Heijden, G.W.A.M.; Tromp, S.O.; Rijgersberg, H.; van Evert, F.; Van Wagenberg, C.P.A.; van der Fels-Klerx, H.J. A protocol for evaluating the sustainability of agri-food production systems-A case study on potato production in peri-urban agriculture in The Netherlands. Ecol. Indic. 2014, 43, 315-321. [CrossRef]

68. Haverkort, A.J.; Hillier, J.G. Cool Farm Tool-Potato: Model description and performance of four production systems. Potato Res. 2011, 54, 355-369. [CrossRef]

69. Carbon Trust. 2011. Available online: https://www.carbontrust.com/resources/reports/technology/ accelerating-marine-energy/ (accessed on 15 May 2018). 
70. Den Boer, L.C.; Brouwer, F.P.E.; van Essen, H.P. STREAM-Studie naar TRansport Emissies van Alle Modaliteiten; CE Delft: Delft, The Netherlands, 2008.

71. Sheer, D.; Konrad, W.; Scheel, O. Public evaluation of electricity technologies and future low-carbon portfolios in Germany and the USA. Energy Sustain. Soc. 2013, 8. [CrossRef]

72. Barratt, M. Understanding the meaning of collaboration in the supply chain. Supply Chain Manag. Int. J. 2004, 9, 30-42. [CrossRef]

73. Blome, C.; Paulraj, A.; Schuetz, K. Supply chain collaboration and sustainability: A profile deviation analysis. Int. J. Oper. Prod. Manag. 2014, 34, 639-663. [CrossRef]

74. Simatupang, T.M.; Sridharan, R. Supply chain discontent. Bus. Process Manag. J. 2005, 11, 349-369. [CrossRef]

75. Simatupang, T.M.; Sridharan, R. The collaboration index: A measure for supply chain collaboration. Int. J. Phys. Distrib. Logist. Manag. 2005, 35, 44-62. [CrossRef]

76. Touboulic, A.; Walker, H. Love me, love me not: A nuanced view on collaboration in sustainable supply chains. J. Purch. Supply Manag. 2015, 21, 178-191. [CrossRef]

77. Lozano, R. Collaboration as a pathway for sustainability. Sustain. Dev. 2007, 15, 370-381. [CrossRef]

78. Beske, P.; Seuring, S. Putting sustainability into supply chain management. Supply Chain Manag. Int. J. 2014, 19, 322-331. [CrossRef]

79. Carter, C.R.; Rogers, D.S. A framework of sustainable supply chain management: Moving toward new theory. Int. J. Phys. Distrib. Logist. Manag. 2008, 38, 360-387. [CrossRef]

80. Beske, P.; Land, A.; Seuring, S. Sustainable supply chain management practices and dynamic capabilities in the food industry: A critical analysis of the literature. Int. J. Prod. Econ. 2014, 152, 131-143. [CrossRef]

81. Van Hoof, B.; Thiell, M. Collaboration capacity for sustainable supply chain management: Small and medium-sized enterprises in Mexico. J. Clean. Prod. 2014, 67, 239-248. [CrossRef]

82. Villena, V.H.; Revilla, E.; Choi, T.Y. The dark side of buyer-supplier relationships: A social capital perspective. J. Oper. Manag. 2011, 29, 561-576. [CrossRef]

83. Prajogo, D.; Olhager, J. Supply chain integration and performance: The effects of long-term relationships, information technology and sharing, and logistics integration. Int. J. Prod. Econ. 2012, 135, 514-522. [CrossRef]

84. Whipple, J.M.; Russell, D. Building supply chain collaboration: A typology of collaborative approaches. Int. J. Logist. Manag. 2007, 18, 174-196. [CrossRef]

85. Nuhoff-Isakhanyan, G.; Wubben, E.F.; Omta, S.W.F. Sustainability benefits and challenges of inter-organizational collaboration in Bio-Based business: A systematic literature review. Sustainability 2016, 8, 307. [CrossRef]

86. Agyemang, M.; Zhu, Q.; Tian, Y. Analysis of opportunities for greenhouse emission reduction in the global supply chains of cashew industry in West Africa. J. Clean. Prod. 2016, 115, 149-161. [CrossRef]

87. Antonio, L.; Griffith, G. The Cashew Value Chain in Mozambique: Analysis of Performance and Suggestions for Improvement. Int. J. Food Syst. Dyn. 2017, 8, 208-221.

88. Dela Cruz, R.S. Accessing the global market for cashew kernel by rural-based processors: The Philippine experience. Acta Hortic. 2007, 23, 91-98. [CrossRef]

89. Venkattakumar, R. Socio-economic factors for cashew production and implicative strategies: An overview. Indian Res. J. Ext. Educ. 2016, 9, 55-62.

90. Figueirêdo, H., Jr. Desafios Para a Cajucultura no Brasil: O comportamento da oferta e da demanda da castanha de caju. Rev. Econ. Nordeste 2006, 37, 550-571.

91. Oliveira, L.G.L.; Ipiranga, A.S.R. Evidences of the sustainable innovation in the cashew agribusiness context in Ceará-Brazil. RAM Rev. Adm. Mackenzie 2011, 12, 122-150. [CrossRef]

92. Laroche, M.; Bergeron, J.; Barbaro-Forleo, G. Targeting consumers who are willing to pay more for environmentally friendly products. J. Consum. Mark. 2011, 18, 503-520. [CrossRef]

93. Jain, A.V.; Hendre, S.B.; Gote, V.H. Cashew Industry from Harvesting to Marketing-Opportunity for Entrepreneurship in India with respect to Ghana. J. Contemp. Res. Manag. 2016, 32-42.

94. Tasca, L.; Nessi, S.; Rigamonti, L. Environmental sustainability of agri-food supply chains: An LCA comparison between two alternative forms of production and distribution of endive in northern Italy. J. Clean. Prod. 2016, 140 Pt 2, 725-741. [CrossRef]

95. Carvalho, B.R.P.; Mendes, H. Cashew Chain Value in Guiné-Bissau: Challenges and Contributions for Food Security: A Case Study for Guiné-Bissau. Int. J. Food Syst. Dyn. 2016, 7, 1-13. 
96. Deepak, B.; Dhar, U.R. Analysing Relationship Dynamics in Cashew Supply Chains. J. Supply Chain Manag. Syst. 2012, 1, 1-12.

97. AliceWeb. 2018. Available online: http:/ / aliceweb.mdic.gov.br/ (accessed on 30 May 2018).

98. Brose, M.E. Cadeias produtivas sustentáveis no desenvolvimento territorial: A castanha na Bolívia e no Acre, Brasil. Interações 2016, 17, 77-86. [CrossRef]

99. D'Souza, G.; Ikerd, J. Small Farms and Sustainable Development: Is Small More Sustainable? J. Agric. Appl. Econ. 1996, 28, 73-83. [CrossRef]

100. Gimenez, C.; Tachizawa, E. Extending sustainability to suppliers: A systematic literature review. Supply Chain Manag. Int. J. 2012, 17, 531-543. [CrossRef]

101. Alves, A.P.F.; Silva, M.E.; Santos, J.G. Colaboração para a sustentabilidade: Práticas de membros de uma cadeia de suprimentos do rio grande do sul. Rev. Gestão Soc. Ambient. 2018, 12. [CrossRef]

102. Perry, C. Processes of a case study methodology for postgraduate research in marketing. Eur. J. Mark. 1998, 32, 785-802. [CrossRef]

103. Rowley, J. Using case studies in research. Manag. Res. News 2002, 25, 16-27. [CrossRef]

104. Yin, R.K. Case Study Research: Design and Methods, 3rd ed.; Applied Social Research Methods Series; Sage Publications; Inc.: Thousand Oaks, CA, USA, 2002; Volume 5.

105. Rosenzweig, P.M.; Singh, J.V. Organizational Environments and the Multinational Enterprise. Acad. Manag. Rev. 1991, 16, 340-361. [CrossRef]

106. Chan, A.; Yung, E.; Lam, P.; Tam, C.; Cheung, S. Application of Delphi method in selection of procurement systems for construction. Constr. Manag. Econ. 2001, 19, 699-718. [CrossRef]

107. Polit, D.; Hungler, B. Nursing Research: Principles and Methods, 6th ed.; Lippincott Williams \& Wilkins: Philadelphia, PA, USA, 1999.

108. Okoli, C.; Pawlowski, S. The Delphi method as a research tool: An example, design considerations and applications. Inf. Manag. 2004, 42, 15-29. [CrossRef]

109. Opdenakker, R. Advantages and disadvantages of four interview techniques in qualitative research. FQS Forum Qual. Soc. Res. 2006, 7, 13-26.

110. Hair, J., Jr.; Anderson, R.; Tatham, R.; Black, W. Multivariate Data Analysis, 5th ed.; Prentice Hall: Upper Saddle River, NJ, USA; Englewood Cliffs, NJ, USA, 2009.

111. Chow, W.; Madu, C.; Kuei, C.; Lu, M.H.; Lin, C.; Tseng, H. Supply Chain Management in the U.S. and Taiwan: An Empirical Study. Omega 2008, 36, 665-679. [CrossRef]

112. Elkington, J. Cannibals with Forks: The Triple Bottom Line of 21st Century Business; Capstone: Oxford: UK, 2002.

113. Monforti-Ferrario, F.; Pascua, I.P. Energy Use in the EU Food Sector: State of Play and Opportunities for Improvement; European Commission: Brussels, Belgium, 2015; Available online: http:/ / publications.jrc.ec. europa.eu/repository/bitstream/JRC96121/ldna27247enn.pdf (accessed on 28 May 2018).

114. Weatherhead, K.; Knox, J.; Daccache, A.; Morris, J.; Groves, S.; Hulib, A.; KaY, M. Water for Agriculture: Collaborative Approaches and on-Farm Storage; FFG1112 Final Report; Cranfield University: Cranfield, UK, 2014.

115. Food and Agriculture Organization of the United Nations. International Code of Conduct on the Distribution and Use of Pesticides; Food and Agriculture Organization of the United Nations (FAO): Roma, Italy. Available online: http:/ / www.fao.org/docrep/018/a0220e/a0220e00.pdf (accessed on 26 May 2018).

116. Beech, N.; Huxham, C. Cycles of identity formation in interorganizational collaboration. Int. Stud. Manag. Organ. 2003, 33, 28-52.

117. Engelseth, P. Food product traceability and supply network integration. J. Bus. Ind. Mark. 2009, 24, 421-430. [CrossRef]

118. Bosona, T.; Gebresenbet, G.; Nordmark, I.; Ljungberg, D. Integrated logistics network for supply chain of locally produced food, part I: Location and route optimization analysis. J. Serv. Sci. Manag. 2011, 4, 174-183. [CrossRef]

119. Pinter, L.; Hardi, P.; Bartelmus, P. Sustainable Development Indicators: Proposals for the Way Forward; Prepared for the United Nations Division for Sustainable Development (UN-DSD); International Institute for Sustainable Development: Winnipeg, MB, Canada, 2005.

120. Department for Environment Food and Rural Affairs (DEFRA). The Strategy for Sustainable Farming and Food: Facing the Future; Defra Publications: London, UK, 2002.

121. Chand, P.; Sirohi, S.; Sirohi, S.K. Development and application of an integrated sustainability index for small-holder dairy farms in Rajasthan, India. Ecol. Indic. 2015, 56, 23-30. [CrossRef] 
122. Tisdell, C.A. Economics of Environmental Conservation; Elsevier Science B.V.: New York, NY, USA, 1994.

123. Sarkis, J.; Zhu, Q.; Lai, K.H. An organizational theoretic review of green supply chain management literature. Int. J. Prod. Econ. 2011, 130, 1-15. [CrossRef] 